\title{
CONTRATO INCOMPLETO: UMA PERSPECTIVA ENTRE DIREITO E ECONOMIA PARA CONTRATOS DE LONGO TERMO
}

\author{
Uinie Caminha e Juliana Cardoso Lima
}

INCOMPLETE CONTRACT: A PERSPECTIVE BETWEEN LAW AND ECONOMICS FOR LONG-TERM CONTRACTS

\section{RESUMO}

O PRESENTE TRABALHO VISA APRESENTAR UMA ANÁLISE DA TEORIA ECONÔMICA DO CONTRATO INCOMPLETO, DEMONSTRANDO A INTERAÇÃO ENTRE OS RAMOS DO DIREITO E DA ECONOMIA, NOTADAMENTE QUANDO O ELEMENTO DE LIGAÇÃO É O INSTITUTO CONTRATUAL. A PARTIR DE ESTUdOS DA DOUTRINA ESTRANGEIRA, PRETENDE-SE TRAZER À ÓRBITA JUDICIAL A VISÃO ECONÔMICA DOS ACORDOS DE LONGA DURACÃO, AMPLIANDO, POR CONSEGUINTE, A HIPÓTESE VIGENTE NO ORDENAMENTO JURÍDICO DA REVISÃO DOS CONTRATOS. ASSIM, A ATUALIDADE DO ASSUNTO, PRINCIPALMENTE NA ESFERA INTERNACIONAL, E A ESCASSA DOUTRINA INTERNA JÁ FUNDAMENTAM A ESCOLHA DO TEMA PARA A CONSTRUÇÃO DE UMA PESQUISA CIENTífICA. NESTE CENÁRIO POUCO EXPLORADO, PRETENDE-SE APRESENTAR AS PRINCIPAIS CARACTERÍSTICAS DA TEORIA ECONÔMICA DO CONTRATO INCOMPLETO. TRATA-SE DE UM ESTUDO QUALITATIVO, CUJA METODOLOGIA SE EFETIVA POR MEIO DE PESQUISA BIBLIOGRÁFICA E DOUTRINÁRIA, TANTO NO ÂMBITO INTERNO COMO EXTERNO, ESTABELECENDO UM DIÁLOGO ENTRE A TEORIA ECONÔMICA DO CONTRATO INCOMPLETO E A TEORIA JURÍDICA DO CONTRATO. COM TAL ESCOPO, SISTEMATIZOU-SE O PRESENTE TRABALHO EM TRÊS CAPÍtUlOS. NO PRIMEIRO, OBJETIVA-SE REALIZAR UMA BREVE EXPOSICC̃̃O SOBRE A RELAÇ̃̃O ENTRE DIREITO E ECONOMIA. O SEGUNDO CAPÍTULO INGRESSA, PROPRIAMENTE, NO ESTUDO DOS PRINCIPAIS PONTOS ABORDADOS NA TEORIA ECONÔMICA DO CONTRATO INCOMPLETO, EM ESPECIAL, OS RELATIVOS AOS CUSTOS DE TRANSAÇÃO. No ÚlTIMO CAPÍTULO, INTENTA-SE APLICAR A TEORIA ECONÔMICA DO CONTRATO INCOMPLETO NO ORDENAMENTO JURídICO. POR FIM, CONCLUI-SE QUE A TEORIA ECONÔMICA DO CONTRATO INCOMPLETO AMPLIA A HIPÓTESE DE REVISÃO, QUE SE BASEIA NA TEORIA DA IMPREVISÃO, INOVANDO, PORTANTO, A ORDEM JURÍDICA.

\section{PALAVRAS-CHAVE}

LAW AND ECONOMICS; CONTRATOS INCOMPLETOS; Custos DE TRANSAÇÃo; REVISÃo CONTRATUAL.

\section{ABSTRACT}

THE SCOPE OF THIS ESSAY IS TO PRESENT AN ANALYSIS OF THE ECONOMIC THEORY OF INCOMPLETE CONTRACTS, INTERACTING LAW AND ECONOMICS, ESPECIALLY THROUGH CONTRACTS. BY STUDYING FOREIGN DOCTRINE, WE AIM AT BRINGING AN ECONOMIC VIEW OF LONG-TERM CONTRACTS INTO JUDICIAL STRUCTURE, EVOLVING THE CURRENT POSSIBILITIES OF CONTRACT REVIEW. HENCE, THE TIMELINESS OF THE SUBJECT, ESPECIALLY IN INTERNATIONAL DOCTRINE AND THE REDUCED INTERNAL DOCTRINE ON THE SUBJECT JUSTIFY ITS CHOICE FOR ACADEMIC RESEARCH. IN THE SCENARIO, THE MAIN CHARACTERISTICS OF THE ECONOMIC THEORY OF INCOMPLETE CONTRACTS SHALL BE PRESENTED. THIS IS A QUALITATIVE STUDY WHICH METHODOLOGY CONSISTS OF BIBLIOGRAPHIC RESEARCH, IN ORDER TO ESTABLISH A DIALOGUE BETWEEN LAW, ECONOMICS AND CONTRACTUAL THEORY. THIS ESSAY IS DIVIDED INTO THREE CHAPTERS. THE FIRST CHAPTER IS DEDICATED TO ESTABLISHING THE RELATION BETWEEN LAW AND ECONOMICS. THE SECOND CHAPTER ANALYSES THE ECONOMIC THEORY OF THE INCOMPLETE CONTRACT AND TRANSACTION COSTS. THE THIRD CHAPTER AIMS AT APPLYING THE ECONOMIC THEORY OF INCOMPLETE CONTRACTS TO OUR LEGAL SYSTEM. AS A CONCLUSION, WE BELIEVE THAT THE ECONOMIC THEORY OF INCOMPLETE CONTRACTS BROADENS THE CASES IN WHICH CONTRACT REVIEW MAY APPLY.

\section{KEYWORDS}

LAW AND ECONOMICS; INCOMPLETE CONTRACTS;

TRANSACTION COSTS; CONTRACT REVIEW. 


\section{INTRODUÇÃO}

O presente trabalho visa apresentar uma análise da teoria econômica do contrato incompleto, demonstrando a interação entre Economia e Direito, quando o meio de ligação é o instituto contratual. A partir de estudos da doutrina estrangeira, pretende-se trazer à órbita judicial a visão econômica dos acordos de longa duração, ampliando, por conseguinte, as hipóteses previstas no ordenamento jurídico de revisão dos contratos.

Nesse cenário pouco explorado, pretende-se apresentar as principais características da teoria econômica do contrato incompleto. Com tal escopo, sistematizou-se o presente trabalho em três partes.

Na primeira, objetiva-se realizar uma breve exposição sobre a relação entre Direito e Economia. Parte-se do desenvolvimento da análise econômica do direito, dando inicial destaque ao pensamento liberal de Adam Smith e a doutrina utilitarista. Em seguida, apresenta-se a escola institucionalista americana, que impulsionará o movimento Law and Economics, já em meados do século XX, transformando-se na Nova Economia Institucional.

Estuda-se, ainda, como se deu a formação da Escola de Chicago, tendo como figura marcante Ronald Coase, que, a partir de obras como The nature of the firm (1937) e The problem of social cost (1960), constatou a influência do Judiciário na atividade econômica. Isso ocorreu após verificar a existência dos custos de transação no mercado, devendo, o Direito, nessa perspectiva econômica, funcionar como um sistema de incentivos.

De igual modo, apresentam-se outros adeptos do pensamento Law and Economics ao expor sobre a interação entre os dois ramos da ciência, permitindo definir o movimento como a aplicação da teoria econômica para o exame da formação, estruturação e impacto do direito (normas e instituições jurídicas) sobre a economia, avaliando, também, a qualidade e eficiência dos instrumentos legais.

Após, introduz-se uma das áreas de estudo do movimento Law and Economics, o tema relativo ao contrato incompleto ou incomplete contract, por meio do qual se abandona a ideia de uma pactuação completa dos contratos de longa duração, por incompatíveis com elementos intrínsecos às relações contratuais do tipo, tais como racionalidade limitada, conduta oportunista e assimetria de informação.

$\mathrm{Na}$ segunda parte, ingressa-se, propriamente, no estudo dos principais pontos abordados na teoria econômica do contrato incompleto. Formaliza-se, primeiramente, um conceito do contrato incompleto, visto como uma técnica de gestão dos riscos existentes em relações contratuais de longo termo, visando a distribuí-los ex post, por meio de uma dimensão cooperativa das partes. Posteriormente, examinamse as formas de incompletude contratual, passando a distinguir a incompletude súbita da deliberada, a inicial da sucessiva e a jurídica da econômica, permitindo, com isso, um melhor enquadramento do tema. Neste trecho, destrincham-se, ainda, as razões 
da incompletude contratual, ou seja, examinam-se os custos de transação e suas principais causas.

Por fim, intenta-se aplicar a teoria econômica do contrato incompleto, modificando aspectos da teoria geral do contrato. Para tanto, inicia-se a terceira parte com uma breve contextualização histórica do instituto contratual, adentrando-se no estudo da hipótese de revisão que se baseia na teoria da imprevisão, por meio da qual se revive a essência da antiga cláusula do direito canônico rebus sic stantibus, sustentando a possibilidade de revisão do contrato em virtude de acontecimento superveniente imprevisível que desequilibre a sua base econômica e imponha a uma das partes obrigação excessivamente onerosa. Em seguida, passa-se a demonstrar como a teoria econômica do contrato incompleto deve ser observada pelos operadores do direito.

Trata-se de um estudo qualitativo, cuja metodologia se efetiva por meio de pesquisa bibliográfica e doutrinária, tanto no âmbito interno como externo, estabelecendo um diálogo entre a teoria econômica do contrato incompleto e a teoria jurídica do contrato.

\section{A TeOria eConômica do CONTRATo incompleto}

O contrato incompleto é analisado por uma das veias de estudo da escola do Law and Economics. A relevância do tema já foi mencionada por Araújo (2007, p. 147), em sua obra Teoria Econômica do Contrato, que, na oportunidade, comentou: "se tivéssemos que escolher as contribuições mais originais e férteis da Análise Económica para a Teoria do Contrato, num lugar cimeiro colocaríamos decerto a intuição da chamada Incomplete Contract Theory", que se baseia nos pressupostos da corrente Neoinstitucionalista ${ }^{1}$ aqui já introduzida, para a qual a análise econômica do direito deve ter como objeto o "impacto que as instituições podem ter no desenho das soluções contratuais" (ARAÚJO, 2007, p. 152).

É a partir da teoria econômica do contrato incompleto que se afasta a ideia de completude contratual, ${ }^{2}$ por restar demonstrado que "nenhum contrato estabelece uma disciplina específica para todos os eventos que poderiam interferir na execução das obrigações"3 (BELLANTUONO, 2005, p. 61). É que especificar todas as possíveis contingências futuras seria uma atividade custosa e, mesmo assim, sujeita a condições de incerteza.

Tendo em vista a relação que a teoria do custo de transação possui com a teoria do contrato incompleto, passa-se, primeiramente, à apreciação dos denominados custos de transação.

\section{I A teoria dos custos de transação}

A ciência econômica não traz uma definição fechada para designar custos de transação. Porém, de forma genérica, Guerinoni (2007, p. 42-43) entende que os custos de 
transação podem indicar as despesas materiais, bem como "o tempo e a energia necessários a conseguir um acordo sobre um direito; mais especificamente, se entenderia indicar o complexo de custos necessários para a negociação, a execução, e a fiscalização de um acordo". Nesse sentido, os custos de transação "compreendem todos os obstáculos que as partes devem enfrentar quando buscam estabelecer relações negociais no mercado" (BELLANTUONO, 2005, p. 59).

Um dos fatores que impulsionaram a teoria econômica dos contratos incompletos foram os custos de transação apresentados inicialmente no estudo formulado por Ronald Coase (1937). Segundo esclarece Araújo (2007, p. 197-198):

O conceito teria ficado porventura no limbo das ideias teoricamente interessantes, mas irrelevantes, se tivesse ficado limitada ao plano de uma macro-comparação entre um estado "friccional" e "não friccional" de mercado, da qual talvez não se pudesse retirar senão corolários triviais, vagamente tautológicos, se não fosse a intervenção de Ronald Coase, que no seu artigo de 1937 recuperou os "transaction costs", colocando-os ao serviço de uma outra comparação, algo inesperada mas agora muito mais relevante do ponto de vista pragmático: a comparação de eficiências entre a solução de mercado e a solução da integração numa empresa como formas de arregimentação e organização dos fatores produtivos - ou seja, a solução "horizontal” de compra no mercado confrontada com a solução de coordenação "vertical” da produção através de factores subordinados a uma organização hierárquica. Foi com essa "inflexão coaseana" que passou a ficar conotado o conceito de "custos de transacção", passando a representar, no âmbito confinado do "equilíbrio parcial”, uma comparação de eficiência entre arranjos institucionais alternativos. [...]. Tratava-se de perceber que uma grande amplitude de soluções económicas está decisivamente condicionada pelo quadro institucional que gera mais elevados ou mais baixo custos de transacção. [...].

Os estudos de Ronald Coase viabilizaram uma nova leitura econômica do papel do mercado e das empresas. Ao explicar a natureza e os limites das empresas, essas são apontadas pelo economista como um mecanismo de redução dos custos advindos das transações realizadas por meio do mercado. Sobre o tema, Decio Zylberstajn (2010, p. 9) acrescenta:

A firma surge como uma resposta otimizadora dos agentes econômicos, quando os custos da organização dos contratos pela via do mercado, excedem os custos da organização interna. Esta visão de Coase parte de um tratamento da firma, não mais como um esteriótipo da função de produção, mas sim como um conjunto de contratos entre agentes especializados, cujo 
gerenciamento tem um custo. [...]. Ao afirmar que firma e mercado são alternativas para a realização das transações, Coase mais do que abrir o caminho para a compreensão da organização interna das firmas e dos mercados, permitiu uma melhor compreensão das relações contratuais, formais e informais, entre as firmas, que bem caracterizam a economia moderna. O seu trabalho amplificou o estudo do crescimento das organizações com grande aplicabilidade para a compreensão da tendência de fusões, aquisições, alianças estratégicas, subcontratações, entre outros tópicos.

De uma abordagem feita pela teoria econômica neoclássica, em que "os agentes econômicos são dotados de racionalidade ilimitada - sendo capazes de absorver e processar toda a informação disponível” (PINHEIRO, 2010, p. 9), cuja preocupação era apenas com os custos de produção, transmuda-se para uma análise dos custos de transação, introduzida pela teoria econômica neoinstitucionalista.

Ocorre, portanto, uma superação da corrente econômica neoclássica no tocante às funções do mercado e das organizações econômicas. Conforme esclarece Guerinoni (2007, p. 41), "diferentemente da doutrina econômica precedente (neoclássica), centrada especialmente na análise da produção e de seus custos, a nova abordagem considera a transação como unidade fundamental de análise”. Nesse sentido, de acordo com Cateb e Gallo (2010, p. 1), as ciências econômicas passam a estudar "a atividade produtiva não somente sob o aspecto do preço, mas considerando a alocação de recursos conforme as leis e os mecanismos de sua aplicação presentes na realidade dos agentes econômicos”.

Foi necessário que Ronald Coase fizesse um estudo pautado na existência ou não do custo de transação nas relações econômicas, tendo Rachel Sztajn (2005, p. 1) oportunamente afirmado que "a inserção dos custos de transação na Economia e na Teoria das Organizações implica a importância do Direito na determinação de resultados econômicos". Segue advertindo:

Se a "firma" pode ser entendida como um nexo de contratos, então problemas de quebras contratuais, de salvaguardas, de mecanismos criados para manter os contratos e, especialmente, mecanismos que permitam resolver problemas de inadimplemento, total ou parcial, dos contratos, sejam tribunais ou mecanismos privados, passam a ter lugar de destaque na Economia. (SZTAJN; ZYLBERSZTAJN, 2005, p. 7)

Em uma análise das organizações, Coase (2010) constatou que os empresários poderiam substituir a via do mercado por uma decisão administrativa, tomada internamente pela empresa. Esse arranjo institucional, contudo, só seria utilizado quando os custos de transação fossem menores. Buscava-se, assim, atingir a eficiência das relações contratuais. 
Ronald Coase estudou, ainda, a relação dos custos de transação com as instituições legais. No Teorema por ele desenvolvido, apenas em um mundo hipotético poderia se cogitar a inexistência de custos de transação, situação em que as instituições legais não influenciariam no desempenho do sistema econômico. Isso ocorreria, pois

[...] a ausência de custos de transacção asseguraria a solução socialmente eficiente em praticamente todas as circunstâncias, em qualquer quadro de afectação inicial de recursos - daí se retirando, a contrario, que é a elevação dos custos de transacção que gradualmente vai requerendo uma mais forte presença da solução jurídica, ao menos daquela que propicie a mais eficiente afectação inicial de recursos. Nesta área o "Teorema de Coase" serve perfeitamente de ponto referencial, de "conceito regulador", e de certo modo poderá dizer-se que os custos de transacção são o instrumento de medida que permite aferir o distanciamento de cada situação concreta em relação a esse padrão ideal [...]. (ARAúJJ, 2007, p. 201)

Como Coase (1990, p. 14) demonstrou em seu ensaio, The problem of social cost, na ausência de custos de transação, não importa a previsão legal, uma vez que as pessoas sempre podem negociar sem custo para adquirir, dividir e combinar direitos. Em contrapartida, em uma análise do mundo real, Coase (2010) concluiu serem positivos os custos de transação e, portanto, por existirem, sofrerão impactos advindos da aplicação de comandos legais, atuando diretamente sobre o comportamento dos agentes econômicos. Diante dessas observações, Sztajn e Zylbersztajn (2005, p. 3) acrescentaram:

A análise econômica deve, então, considerar o ambiente normativo no qual os agentes atuam, para não correr o risco de chegar a conclusões equivocadas ou imprecisas, por desconsiderar os constrangimentos impostos pelo Direito ao comportamento dos agentes econômicos.

O Judiciário, portanto, atua como instrumento de alocação de incentivos e, por isso, influi na economia. Razão pela qual deve estimular comportamentos cooperativos, visando, consequentemente, reduzir os custos de transação.

A teoria dos custos de transação chama atenção, "por um lado, na forma como os custos condicionam as escolhas das partes [...] e, por outro lado, na forma como a lei pode, influenciando esses custos, presidir a esse condicionamento" (ARAÚJO, 2007, p. 162). Os custos vinculados às transações devem ser compreendidos como todas as barreiras as quais estão sujeitas as partes no ato de instalação das relações contratuais firmadas no mercado. Para Bellantuono (2005, p. 59-60), "é possível, assim, afirmar que a análise econômica do Direito dos Contratos consiste na individualização dos vários tipos de custos de transação e das regras que procuram reduzir sua existência”. 
E ainda, conforme ensina Rachel Sztjan (2010, p. 5-6):

Os custos de transação são aqueles incorridos na realização de uma operação econômica, representados, ou não, por dispêndios financeiros, mas que decorrem do conjunto de ações e medidas adotadas por cada pessoa (ou parte) antes, durante e depois de consumada a operação econômica. Custos de transação são o esforço na procura de bens em mercados, a análise comparativa de preço e qualidade antes de tomar a decisão, o desenho da garantia quanto ao cumprimento das obrigações pela outra parte, a certeza do adimplemento, seguro e a tempo, as garantias que se exija para fazer frente a eventual inadimplemento ou adimplemento imperfeito pela contraparte, a redação de instrumentos contratuais que reflitam as tratativas entre contratantes e disponham sobre direitos, deveres e obrigações. Cuidados e tempo despendido desde o início da procura pelo bem, passando pela decisão de realizar a operação ou transação, o cumprimento de todas as obrigações pelas partes contratantes e as garantias para tanto, incluindo as relacionadas a eventual inadimplemento - custo de demandar em juízo ou qualquer forma de solução de controvérsias - são, pois, custos de transação.

Ainda sobre o tema, deve-se mencionar que os custos de transação não dependem apenas das características do acordo firmado, pois, também são resultantes das condutas das partes, em especial, quando se comportam com racionalidade limitada e oportunismo, bem como de condições objetivas, como as incertezas das transações decorrentes das mudanças sociais, a duração e os investimentos específicos do contrato, fatores inerentes às relações contratuais de longo prazo.

Em virtude das características elencadas, ao interagirem sistema econômico e sistema jurídico, os custos de transação aparecem como fatores imprescindíveis de apreciação, por serem considerados os principais motivos da incompletude contratual, já que é difícil conceber qualquer atividade econômica, como a construção de um edifício comercial ou a implantação de um programa de informática, sem que haja a necessidade de emprego de recursos, como "a coleta de informações, a redação dos contratos, a coordenação entre os diversos atores econômicos e a resolução de controvérsias" (BELLANTUONO, 2005, p. 8).

Consoante a teoria econômica do contrato, o conceito de custos de transação está relacionado aos custos de redação do clausulado, aos custos de disciplina contratual e às contingências imprevistas, estando, ainda, condicionado as assimetrias e insuficiências advindas da ignorância racional, as diferenças de poder negocial ou de mercado (ARAÚJO, 2007, p. 199).

Os custos de transação condicionam as escolhas das partes. Por existirem, os contratos que se prologam no tempo não podem ser completos, pois além de ser muito 
oneroso estipular todas as contingências futuras, existem fatores de elevação dos custos de difícil estipulação.

Por isso, para compreender a teoria econômica do contrato incompleto, é necessário conhecer a teoria dos custos de transação e, consequentemente, adentrar no exame dos fatores relativos à racionalidade limitada e à conduta oportunista das partes, bem como analisar os pontos relacionados com as incertezas dos contratos de longo termo, a duração e complexidade do negócio e, por fim, os investimentos em ativos específicos presentes em contratos do tipo.

\section{O CONCEITO DE CONTRATO INCOMPLETO}

Parte-se da premissa que o contrato incompleto é uma técnica de decisão presente no ato de gerir as relações contratuais que se caracterizarem pelo grau de complexidade e problema, já que reflete "a capacidade limitada de se descrever os infinitos estados da natureza, predispor medidas para execução da operação, se ou quando, sofrerem alterações" (SZTJAN, 2010, p. 14).

$\mathrm{Na}$ busca pela eficiência contratual, os contraentes "podem assim preferir um contrato flexível a um contrato que apresente uma alocação de risco ex ante rígida e imutável” (GUERINONI, 2007, p. 8), pois o contrato flexível possibilita remediar a previsão defeituosa em momento posterior à contratação.

Segundo a teoria econômica, os contratos, sejam eles onerosos ou não, são sempre incompletos, já que "é impossível pressupor todos os acontecimentos ou eventos que poderão ter lugar entre os seres humanos, em especial no futuro" (PINHEIRO; SADDI, 2005, p. 117). Sendo assim, os contratos incompletos são "instrumentos cujo desempenho de seus termos contratuais deixam ganhos potenciais da transação irrealizados, face às informações disponíveis para os agentes e para as cortes de justiça” (CATEB; GALLO, 2010, p. 2). É que

[...] quaisquer que sejam as transações, as partes envolvidas não sabem ao certo se os termos acordados serão efetivados. A razão é que os indivíduos possuem racionalidade limitada e comportamento oportunista, acarretando o surgimento de custos de transação, que poderiam ser minimizados pela cooperação das partes contratantes no momento da execução do objeto contratual. Também a assimetria informacional se junta ao oportunismo dos agentes para restringir a elaboração de contratos completos, causando custos de transação. Tais custos associam-se a coletas de informações, à elaboração e negociação dos contratos, além dos custos pós-contratuais, decorrentes da inexecução das obrigações. (CATEB; GALLO 2010, p.3)

Verifica-se que o custo de transação é o elemento que a Escola de Chicago identifica 
como responsável pela incompletude dos contratos, podendo se apresentar em razão da racionalidade limitada das partes, principalmente quando os contraentes estão diante de decisões complexas, já que nem sempre os indivíduos possuirão todas as informações necessárias para se alcançar a decisão "ótima”, bem como em virtude da assimetria de informação, da conduta oportunista, dentre outros fatores. Como bem adverte Bellantuono (2005, p. 61), "na maior parte dos casos, as escolhas se baseiam em uma quantidade de informação decisivamente restrita”. Nesse contexto, Araújo (2007, p. 151) leciona:

O inacabamento contratual é a resposta pragmática a um contexto econômico e jurídico eivado de imperfeições e incertezas - é o fruto da constatação de que talvez não valha a pena alongar as negociações quando as resultantes estipulações não erradicariam ou cobririam eficiente os riscos subsistentes, ou quando elas se tornassem insusceptíveis de desencadear reações tutelares adequadas.

A realização de um contrato mais próximo do completo demandaria um maior desembolso para a sua elaboração e execução, permanecendo, mesmo assim, "fora do contrato os cenários, que, no momento da conclusão, parecem altamente improváveis ou mesmo inimagináveis” (BELLANTUONO, 2005, p. 62). Nesse sentido é que o contrato incompleto deve ser definido como "um modelo alternativo de administração de riscos, caracterizado por uma lógica de decisão e alocação de riscos ex post, ou seja, “o contrato incompleto não aloca ex ante, os riscos entre as partes, mas determina um procedimento para alocação ex post” (FICI, 2005, p. 125). Objetiva-se, portanto, segundo Fici (2005, p. 125), "criar um clima de cooperação 4 entre as partes. As partes que concluem um contrato incompleto devem-se presumir-se avessas ao risco da operação econômica, que pretendem gerir ex post em uma dimensão cooperativa”.

A respeito, Rachel Sztjan (2010, p. 5), comenta:

A complexidade de certas operações de comércio internacional em que há vazios, ambiguidades ou lacunas no clausulado negocial, quando o idioma pode constituir barreira para a exata compreensão do regramento, acomoda bem a ideia de contrato incompleto dos economistas, sendo, talvez, mais evidente a importância de entender os argumentos em que se baseiam ao discutir eficiência e incentivos das partes; em que o receio de que complementos feitos por terceiros, cujas informações sobre o negócio serão sempre de pior qualidade do que a das partes, inclusive a da menos informada, são vistos como fontes de dificuldades; quando se referem a incentivos corretos para o sucesso das operações. 
A teoria econômica, ao apresentar o contrato incompleto, busca agregar aos conhecimentos jurídicos uma nova hipótese de revisão dos contratos. Fixada a premissa de que os custos de transação inviabilizam a feitura de um acordo completo, passa-se à exposição das formas de incompletude do contrato.

\section{I AS FORMAS DE INCOMPLETUDE CONTRATUAL}

Neste tópico, objetiva-se demonstrar as formas de incompletude contratual, apresentando expressões e conceitos identificados na doutrina estrangeira, que serão indispensáveis para um melhor enquadramento do que se entende por contrato incompleto, tais como a incompletude súbita e incompletude deliberada, incompletude inicial e incompletude sucessiva, incompletude jurídica e incompletude econômica. De posse das definições apresentadas, coloca-se em questão o poder do ordenamento de completar os acordos lacunosos e a forma que tal poder será exercido.

As balizas que envolvem a teoria do contrato incompleto são destinadas aos contratos de longa duração ou de execução diferida, ${ }^{5}$ não sendo aplicáveis, por despiciendo, àqueles de execução imediata, de lapso temporal quase que imperceptível. Assim, pela corrente do Law and Economics, excetuando-se os contratos de execução instantânea, os contratos de longo termo apresentam-se incompletos. Tal incompletude ocorre porque determinadas questões podem passar despercebidas ou imprevistas pelas partes que firmam o contrato. Segundo Pinheiro (2010, p. 7):

Há várias razões para se redigir contratos incompletos: por exemplo, a dificuldade de prever todas as futuras contingências, a complexidade de especificar por escrito todas as regras que prevalecerão para cada contingência que se possa prever, e a dificuldade de se observar e verificar a ocorrência de muitas contingências, para que se possa determinar se as ações contratualmente previstas devem ser colocadas em prática.

Entretanto, a incapacidade ou insuficiência de prever todas as situações futuras atinentes a negociação não é a única causa que leva à incompletude contratual, que pode derivar, ainda, de ato intencional dos contraentes. A incompletude pode funcionar, portanto, como estratégia contratual, cabendo às partes, no intuito de melhor gerir seu negócio, analisar se diante de determinado contexto econômico é indicado estipular o maior número possível de cláusulas ou, ao contrário, deixar uma cláusula de abertura, em que se possa prever a sua sucessiva determinação. Nesse sentido, afirma Marasco (2006, p. 16):

Se a intenção dos contratantes é de planejar cada aspecto da operação que pretendem realizar, preferem um contrato "fechado", mediante o qual cada 
elemento do contrato (prestação, contraprestação, modalidade de execução etc.) é precisamente determinado desde o início. Se, ao contrário, é intenção dos contratantes evitar, desde o início, o risco superveniente capaz de alterar o equilíbrio econômico do contrato, o esquema negocial preferido é o aberto, pelo qual a contraprestação, ao invés de ser rigidamente predeterminada, é calculada de acordo com a despesa efetivamente suportada na execução da prestação.

Tais hipóteses serão examinadas a seguir, tendo como objetivo apresentar expressões usuais da teoria do contrato incompleto e clarear os pontos abordados que, ainda, não fazem parte da doutrina brasileira do direito contratual.

\section{I. I INCOMPLETUDE SÚBITA E INCOMPLETUDE DELIBERADA}

Inicialmente serão estudadas duas importantes expressões ligadas à teoria do contrato incompleto: incompletude deliberada e incompletude súbita. A respeito da primeira, Fici (2005, p. 11) leciona que o contrato deliberadamente incompleto deve ser entendido como "aquele contrato cujo conteúdo apresenta uma lacuna, visto que as partes atribuíram a um terceiro, a uma delas ou a um acordo posterior a determinação do elemento ausente".

Nesse sentido, há, portanto, um desejo das partes em deixar em aberto determinadas cláusulas, por entenderem que suposta necessidade de complemento poderá ser suprida por meio de deliberação sucessiva (mediante uma maior cooperação entre as partes, visando a atingir um nível ótimo de completamento), a depender da estratégia contratual oportunamente adotada por elas. O contrato incompleto apresenta-se, assim, como um instrumento de grande utilidade para gerir as "operações econômicas complexas que se desenvolvem em um contexto de incerteza e são destinadas a perdurarem no tempo" (FICI, 2005, p. 12).

Verifica-se que a incompletude deliberada ou intencional do contrato está intimamente relacionada à ideia de estratégia contratual, cabendo às partes, quando deixarem algum elemento do contrato em branco, optarem por uma técnica particular de gestão contratual dos riscos oriundos de uma operação econômica (FICI, 2005, p. 22). A incompletude deliberada envolve, assim, um decidir de não decidir, ou um decidir de decidir sucessivamente. Cooter e Ulen (2010, p. 223) exemplificam:

Um contrato talvez não diga nada sobre a possibilidade de que uma greve ilegal impeça o fabricante de produzir as mercadorias prometidas. As partes talvez deixem esta lacuna deliberadamente no contrato por crerem que a possibilidade de uma greve seja remota. Os riscos remotos não justificam o custo da negociação e elaboração das condições para alocar esses riscos $[\ldots]$. 
Para Araújo (2007, p. 156), a incompletude deliberada, que o referido doutrinador português denomina de inacabamento deliberado ou estratégico, "honestamente visa alcançar um nível óptimo de completamento ou aquele que maliciosamente visa deixar interstícios no clausulado para serem explorados ex post".

Como visto, a incompletude deliberada é uma técnica convencional de complemento de lacunas presentes no conteúdo do contrato. Quanto ao tema, Guerinoni (2007, p. 1) lembra que, "em geral, por lacuna (no conteúdo de um contrato) se entende a falta de previsão explícita por parte dos contratantes na ocasião de conclusão do contrato". Assim, a incompletude do contrato, nesta hipótese, é consequência das técnicas de contratação e/ou das diversas modalidades de conclusão do contrato, diferenciando-se quanto ao grau de complexidade do acordo ${ }^{6}$ (GUERINONI, 2007, p. 2).

No entanto, Antonio Fici (2005) leciona que a incompletude pode ser súbita, opondo-se a incompletude deliberada, principalmente quanto ao elemento "volontà", já que na deliberada ou estratégica, as partes, por vontade própria, deixam em aberto alguma cláusula do contrato, o que não acontece na incompletude súbita, cujo conteúdo do contrato possui uma lacuna sem que tenha havido uma intenção dos contraentes.

Para uma melhor compreensão, utiliza-se de um exemplo fornecido por Cooter e Ulen (2010, p. 233): "suponha que um contrato não diga nada sobre a possibilidade de que um sequestro feche um aeroporto e impeça o vendedor de fornecer mercadorias pontualmente”. O não regulamento voluntário de algum ponto do contrato no ato de sua conclusão, assim como a falta de estipulação quanto à possibilidade de sua determinação sucessiva, também deixa incompleto o contrato (incompletude súbita ou involuntária), acarretando, ainda, nessa hipótese, a aplicação do procedimento de integração ou interpretação, disciplinado pela norma legal, haja vista a concepção de completude do ordenamento jurídico retratada por Norberto Bobbio em seu livro Teoria do ordenamento jurídico. ${ }^{7}$

Como afirma Fici (2005, p. 23-24), a incompletude súbita pode assumir duas formas: uma aparente e outra real. Esta diz respeito às lacunas presentes no regramento contratual que são oriundas da "ambiguidade ou vagueza da linguagem utilizada pelas partes, e, portanto, de um defeito na declaração e/ou comunicação, ou, ainda, de uma verdadeira ausência de vontade, e assim de um defeito de vontade e/ou representação”, que o ordenamento supre com integração. Em relação à aparente, é espécie de incompletude que o ordenamento supre com interpretação.

De maneira mais detalhada, Guerinoni (2007, p. 3) pontua que a incompletude pode ocorrer: a) pelo mero esquecimento dos contratantes de disciplinar um ponto do acordo; b) pela consciência das partes da substância de norma dispositiva que preenche a lacuna, fazendo os contraentes não discorrerem sobre uma regulamentação alternativa; c) pela escolha estratégica de um dos contratantes que, ao contrário da outra parte, conhecendo a norma dispositiva que se aplica ao negócio, prefere não 
abordar quanto a este aspecto para poder, posteriormente, valer-se da norma dispositiva, provavelmente a ele mais favorável.

Resta evidenciada a distinção entre incompletude súbita e incompletude deliberada, já que nesta última os contraentes são conscientes de que, no ato de conclusão do contrato, uma parcela do seu conteúdo deve ser determinada posteriormente e que a lacuna será preenchida, alternativamente, por um outro acordo, pela determinação de apenas uma das partes, ou pela decisão de um terceiro. Situação diversa da incompletude súbita ou involuntária, em que as partes não tiveram a intenção de deixar lacunas no contrato, preferindo que o contrato incompleto venha disciplinado pelas normas legais (mediante o procedimento de integração ou interpretação). ${ }^{8}$

Guerinoni (2007, p. 6) relaciona, ainda, a incompletude deliberada aos contratos comerciais internacionais de longa duração, dos quais emerge uma tendência de considerar a determinação do conteúdo do acordo como um processo destinado a ficar aberto, guardando entre os contraentes um "vínculo de cooperação", termo utilizado para definir os relacionamentos entre empresas que unem seus esforços visando a perseguir um objetivo comum, não antagônico, tais como as joint-ventures, os consórcios e as associações de empresas.

Não é tarefa elementar distinguir quando a incompletude é súbita ou deliberada, o que resulta na dificuldade de rever as cláusulas contratuais. Porém, as peculiaridades oriundas do inacabamento contratual geram efeitos significativos quanto à possibilidade de intervenção por parte dos juízes. Logo, conforme dispõe Guerinoni (2007, p. 7-8):

O fato de a conclusão do contrato ser precedida de uma longa e complexa negociação não influencia, por si só, no grau de completude do conteúdo, já que, pelas mais variadas razões, é possível que alguns aspectos não sejam regulados (talvez porque as partes tenham-se concentrado na definição de algumas e esqueceram-se de outras, que a seu ver eram "secundárias"; ou ainda pode ocorrer que, por conta, por exemplo, da complexidade do contrato (venda de uma participação acionária de controle de uma holding), os contraentes preferem remeter a determinação de um elemento (importante) do contrato (o preço) a um terceiro (um especialista ou conjunto de especialistas) se discutiram longamente sobre outros aspectos relevantes do acordo (como por exemplo o conteúdo das garantias).

Consoante preceitua Araújo (2007, p. 184), “em ambientes economicamente dinâmicos e sofisticados, na proximidade de mercados densos e concorrenciais, é de esperar que cresça o número de contratos com cláusulas abertas e com inacabamento deliberado". Posterga-se, para o futuro, o encontro de soluções, ainda que se tenha a cautela de indicar um núcleo intocável de escolhas, permitidas ou proibidas. 


\section{I.2 INCOMPLETUDE INICIAL E INCOMPLETUDE SUCESSIVA}

Outra classificação da doutrina estrangeira que deve ser objeto de exame é a de incompletude inicial e incompletude sucessiva, que derivam da apresentada incompletude deliberada.

A incompletude deliberada subdivide-se, portanto, em incompletude deliberada inicial (ou originária), manifestando-se na conclusão do contrato e, em razão da existência de uma cláusula de abertura ou de incompletude deliberada sucessiva, em que há uma postergação da determinação do objeto do contrato ou, mais propriamente, há "uma abertura do regramento contratual originariamente (mas não definitivamente) completo" (FICI, 2005, p. 25). A respeito disso, Fici (2005, p. 25-26) complementa:

As partes, de fato, podem decidir deixar o objeto indeterminado ao tempo da conclusão do contrato, ou determiná-lo imediatamente, mas, ao mesmo tempo, submeter essa determinação a um termo ou condição, programando, assim, a determinado período ou à realização de um evento futuro e incerto, uma atividade sucessiva de determinação.

Na prática, a incompletude inicial é mais frequente nos contratos de execução diferida, como na hipótese de um contrato de compra e venda, em que fique estipulado que o comprador (ou o vendedor) possa escolher as modalidades de pagamento, aplicando-se aos contratos de execução continuada ou periódica a incompletude sucessiva, presente no exemplo do contrato de leasing de cinco anos, em que a taxa mensal seja equivalente a um determinado montante, e a previsão, depois do terceiro ano ou na ocorrência de um determinado evento, de sua redeterminação, a ser realizada pelas partes, ou por um terceiro.

A incompletude sucessiva, ou também denominada superveniente, é a que mais ocorre concretamente, produzindo uma modificação no conteúdo preexistente do contrato e demonstrando que a determinação do objeto contratual não é uma atividade estática, mas sim dinâmica. Assim, "a categoria de incompletude sucessiva sinaliza que os problemas do objeto e de sua determinação não se exaurem com a conclusão do contrato, mas podem interessar mesmo na execução” (FICI, 2005, p. 28). No dizer de Guerinoni (2007, p. 9), “o contrato pode ser incompleto tanto porque seu conteúdo é lacunoso no momento da conclusão, quanto porque as partes, concluindo um contrato completo por si só, preveem expressamente que, decorrido certo período ou alteradas algumas condições, deverá ser procedida sua revisão.”

As mudanças de circunstâncias, ou melhor, os riscos da atividade econômica são de ordem econômica (flutuações das taxas de cambio), política (guerra, golpe de Estado, usurpação) e natural (epidemia e catástrofe natural), estando inseridos no ordenamento pátrio como fatores que impõem as partes a resolução do contrato ou seu adimplemento. Porém, a teoria do contrato incompleto disciplina que o modo 
mais simples e imediato para revolver a questão da superveniência contratual, consiste na alocação convencional do risco, ou seja, as partes devem ser livres para melhor alocar os riscos, sendo-lhes facultado inserir cláusula que imponha uma obrigação de modificação do regulamento contratual, ou que conceda à terceiro o poder de adequação.

\section{I.3 INCOMPLETUde JURÍdiCA E INCOMPLETUdE ECONÔMICA}

Conhecer a distinção jurídica e econômica de incompletude contratual é de suma importância para uma melhor compreensão da teoria dos contratos incompletos, já que possuem conotações distintas, pois, para o Direito, a incompletude é associada à ideia de insuficiência, no sentido de que os integrantes da relação contratual não estipularam adequadamente todas as obrigações dela oriundas, favorecendo o nascimento de litígios. De outro lado, como já analisado, a Economia, apesar de reconhecer esse sentido jurídico, também faz referência à incompletude deliberada, atrelada à vontade das partes, em preservar inacabado o acordo, e à incompletude estrutural. Neste sentido, Araújo (2007, p. 156) ministra:

O conceito de inacabamento contratual tem conotações bem distintas para o Direito e para a Economia. Em termos jurídicos trata-se geralmente de um mal, a insuficiente especificação das obrigações emergentes do contrato, com tendência a repercutir em níveis socialmente indesejáveis de litigiosidade e de litigância. O sentido econômico engloba naturalmente esse sentido jurídico, acrescentando-lhe ao menos dois outros: o do inacabamento deliberado ou estratégico [...] e o do inacabamento estrutural, ou seja, aquela margem inerradicável de incerteza que sempre acompanha as relações contratuais não-instantâneas, e que seria fisicamente impossível ou economicamente impraticável tentar resolver (aquilo que o próprio Direito acaba por reconhecer ao admitir para todos os contratos, independentemente do respectivo grau de acabamento, situação de alteração das circunstâncias e de impossibilidade superveniente).

$\mathrm{Na}$ visão dos juristas, o contrato é incompleto quando não regula explicitamente alguns aspectos da relação. Distancia-se da maneira dos economistas apreenderem o clausulado, para os quais o contrato é incompleto quando não estabelece ações e ganhos para as partes em todos as situações possíveis (BELLANTUONO, 2005, p. 62). A respeito, Guerinoni (2007, p. 45-46) acrescenta:

A incompletude assume duas acepções: uma econômica e outra mais propriamente jurídica; por incompletude econômica do contrato se entende, em particular, a circunstância de que o contrato não disciplina 
todas as "possibilidades” [...], não liga as ações das partes a todas as possíveis contingências; nesse caso, assim, não é necessário - para demonstrar a incompletude do negócio, que o contrato apresente uma lacuna, sendo suficiente que o acordo inicial não tenha previsto uma circunstância capaz de influir nos ganhos esperados de uma das partes [...] A incompletude na acepção econômica é estritamente ligada ao problema da assunção, por parte dos contraentes, dos riscos inerentes ao contrato.

Constata-se que a incompletude jurídica e a econômica possuem pontos claramente distintivos, sem risco de se confundirem. A presença de lacunas jurídicas em nada se assemelha a escolha livre (voluntária) das partes em não disciplinar ex ante todas as contingências econômicas. Sobre esse ponto, Rachel Sztjan (2010, p. 26) comenta:

A incompletude econômica pressupõe incapacidade fisiológica do contrato e dos contratantes de lidar com todas as modificações de circunstâncias posteriores à sua conclusão. A jurídica pressupõe que eventuais lacunas, mesmo as involuntárias, serão completadas por normas supletivas, princípios gerais de direito, interpretação, e integração, razão pela qual o contrato incompleto o é enquanto não interpretado ou integrado. Assim, se há instrumentos para completar o contrato, a discussão parece vazia ainda que os estados da natureza mudem. Mas, quando as lacunas deliberadas se destinarem a incentivar negociação futura, facilita-se que cada parte decida, de maneira ótima, em relação a cada evento, tornando mais eficientes as alocações de recursos.

De acordo com a distinção apresentada, é possível verificar o intenso relacionamento existente entre o contrato incompleto e o risco de superveniências, por traduzir, aquele, uma forma alternativa de gestão dos riscos supervenientes, não o fazendo, portanto, pela aplicação da disciplina legislativa (FICI, 2005, p. 21-22).

\subsection{As RAZÕES DA INCOMPLETUDE DO CONTRATO}

A princípio, não se poderia fugir à tentativa de conceituar o contrato completo. Para tanto, usa-se a definição feita por Cateb e Gallo (2010, p. 2), para os quais, os contratos completos "seriam aqueles capazes de especificar, em tese, todas as características físicas de uma transação, como data, localização, preço e quantidades, para cada estado da natureza futuro".

De outra forma, Rachel Sztjan (2010, p. 14) define os contratos completos como aqueles que "exploram todas as distinções verificáveis entre estados da natureza, quando a execução é boa tendo em vista dificuldades das partes em distinguir todos os estados da natureza e a habilidade dos julgadores para verificar que estado ocorreu”. 
Verifica-se, portanto, que os contratos completos só seriam passíveis de ser firmados abstratamente, já que é impossível delimitar todas as contingências futuras, mormente quando condições de incerteza atuam sobre as relações contratuais de longa duração ou de execução diferida.

Assim, a teoria dos contratos incompletos aponta os fatores que acarretam nas imperfeições para a formação do contrato, pois, mesmo que as partes realizem um apurado estudo, “antes da elaboração do contrato, este pode não ser perfeito, e quase nunca o é, visto que existe a possibilidade das partes não serem capazes de antecipar, identificar e descrever respostas ótimas aos eventos futuros" (CATEB; GALLO, 2010, p. 4).

Em verdade, as partes contraentes não têm certeza de que o acordo será efetivado em conformidade com o estipulado em sua conclusão. Isso se dá em virtude da existência dos custos de transação, decorrentes de características objetivas, como a incerteza, a duração e os investimentos em ativos específicos, ou de características subjetivas, tais como a racionalidade limitada e o oportunismo negocial, fatores que serão apreciados a seguir.

\subsection{A RACIONALIDADE LIMITADA DAS PARTES}

A análise econômica neoclássica parte da racionalidade plena dos agentes e, diante desta premissa, elabora as suas teorias. ${ }^{9}$ No entanto, a teoria econômica da incompletude contratual parte da capacidade cognitiva limitada dos atores econômicos, realizando, a partir dessa característica, uma nova teoria pautada no papel desempenhado pelas instituições normativas e nos fatores propulsores dos custos de transações. Conforme ensina Fici (2000, p. 94):

O conceito de racionalidade limitada é estritamente ligado, e às vezes é mesmo dependente, do problema dos custos necessários para adquirir informação e processá-la corretamente. [...]. Tendo em vista que a busca de informação é uma atividade custosa e que capacidade humana de processar informação é limitada, quanto mais as decisões se tornam complexas e envolvem mais trocas, a ideia de racionalidade limitada é a de que os agentes não vão buscar as decisões "ótimas", mas apenas aquelas "satisfatórias".

A conduta dos sujeitos é apenas limitadamente racional.

A racionalidade limitada ou bounded rationality está localizada entre o que se compreende por racionalidade plena ou máxima e por irracionalidade. Apesar das barreiras do conhecimento e dos custos derivados da busca por informações, a racionalidade limitada implica uma conduta racional das partes, por manifestar, ao menos, uma decisão satisfatória. Conforme explica Guerinoni (2007, p. 43), “o termo racionalidade limitada faz referência aos limites cognitivos aos quais os homens estão sujeitos”, 
sendo essa característica a origem da impossibilidade das partes de visualizar e regular todas as contingências. Por isso, é possível falar em agentes humanos "racionais na intenção, mas, de fato, limitadamente racionais” (GUERINONI, 2007, p. 49).

Para Pinheiro (2010, p. 9), a racionalidade limitada é "uma forma de racionalidade imperfeita que assume que as pessoas buscam maximizar o seu bem-estar, mas sujeitas a restrições cognitivas que limitam a sua capacidade de processamento mental”, criando um obstáculo na formação de escolhas ótimas. Entendimento, esse, oposto à doutrina precedente que tinha como premissa a racionalidade dos agentes. É o que atesta Salama (2010, p. 25):

Não por outro motivo, a pesquisa em Direito e Economia há muito tempo se vem afastando do paradigma da hiper-racionalidade, geralmente substituindo-o pela noção mais flexível de "racionalidade limitada". Reconhecendo que os indivíduos nem sempre irão processar as informações disponíveis de forma ótima (ou simplesmente não terão acesso a todas as informações pertinentes), os mesmos passam a ser vistos como "intencionalmente racionais" ainda que limitados por aptidões cognitivas.

Reconhece-se, assim, que existem limites no processo de coleta de informações e que, em razão disso, as informações adquiridas e elaboradas são incompletas, além de traduzirem em um custo a ser suportado pelas partes contraentes. Conforme leciona Araújo (2007, p. 212), os custos de agência são uma variante dos custos de transação, por conciliar "as perspectivas desta última com a consideração dos factores de ineficiência que emergem da assimetria informativa e se manifestam em problemas 'friccionais' de motivação e supervisão dos 'agentes' que encabeçam a vida empresarial”.

Em virtude do custo de informação, os agentes econômicos "preferem tomar decisões fundando-se intencionalmente em um espectro de conhecimento mais limitado do que aquele objetivamente possível" (GUERINONI, 2007, p. 50). Isso ocorre e é, portanto, considerada manifestação racional, porque as restrições feitas comportam uma economia superior em comparação às vantagens que as partes poderiam obter se realizassem uma busca mais ampla. Admitida "a impossibilidade de se conseguirem decisões ótimas (optimal substantive decisions) os agentes econômicos se contentam em tomar decisões ao menos satisfatórias (satisfactory substantive decision)" (GUERINONI, 2007, p. 51).

Diferencia-se optimal decisionmaking procedure de satisfactory decisionmarking procedure. Segundo o primeiro modelo, "um agente investe em busca por informação até que o custo de buscas adicionais iguale o retorno marginal esperado de tais buscas" (FICI, 2000, p. 95), ou seja, a decisão é ótima quando os custos marginais são iguais aos benefícios marginais. ${ }^{10}$ Nessa linha, Cooter e Ulen (2010, p. 45) ilustram o ótimo econômico: 
Comecemos supondo que o tomador de decisões escolha algum nível inicial de uma coisa qualquer que ele esteja interessado em maximizar. Depois tenta determinar se esse nível inicial é seu máximo; será esse nível o melhor que ele consegue, em vista de suas restrições? Ele pode responder a pergunta fazendo mudanças muito pequenas - o que os economistas chamam de marginais - em relação ao nível inicial.

Suponhamos que o tomador de decisões proponha aumentar o que ele estiver fazendo levemente acima de seu nível inicial. Haverá um custo associado a esse pequeno aumento que se chama custo marginal. Mas também haverá um benefício resultante de ter ou fazer mais do que quer que seja que ele está tentando maximizar. O benefício resultante desse pequeno aumento se chama benefício marginal.

Para o outro modelo, ao contrário, "O agente decide, antes de iniciar a pesquisa, o nível de satisfação que pretende alcançar. Assim, prossegue na pesquisa até que atinja a alternativa que satisfaça seu nível predeterminado de aspiração.” (FICI, 2000, p. 96).

Alguns defeitos caracterizam o processo de elaboração das informações, tais como representativeness, faulty telescopic faculty, disposition, faulty risk-estimation faculty e availability, tendo Guerinoni (2007, p. 52-53) mencionado a respeito:

O termo "representativeness" refere-se à adequação limitada e relativa dos dados colhidos para formulação de um juízo. [...] Muitas vezes, os agentes preferem interromper sua pesquisa antes de haver colhido todos os dados; objetivamente, a sua decisão se baseará necessariamente em um subconjunto de dados considerados representativos. [...]. O outro defeito cognitivo relevante consiste na "faulty telescopic faculty", vale dizer, na incapacidade dos agentes humanos de comparar racionalmente estados do mundo presentes e futuros; e, ao comparar os custos e as vantagens atuais com as vantagens e custos futuros, os agentes tendem a dar peso reduzido aos últimos em relação aos primeiros. [...] "Disposition": os agentes humanos são, muitas vezes, realisticamente otimistas; quando devem confronta-se com eventos futuros e incertos, tendem a supervalorizar as próprias probabilidades de sucesso; tendem a dar maior peso à probabilidade de se verificar um evento favorável que o contrário; [...] "faulty risk-estimation faculty" se evidencia que os agentes tendem a proteger-se apenas contra os riscos entendidos como muito prováveis, enquanto tendem a ignorar aqueles mais improváveis [...]. Por fim, a "availability" refere-se ao modo pelo qual um agente arquiva dados adquiridos e imagina cenários futuros. Quando se deve efetuar um juízo sobre a possibilidade de 
um evento, somente se baseia naqueles cenários e naqueles dados comparáveis que estão disponíveis (available) na memória e na imaginação. $[\ldots]$.

No cenário dos últimos anos, os juri-economistas, utilizando-se da psicologia cognitiva, deram luz ao movimento denominado Law and behavioural science, passando a estudar o perfil comportamental dos atores econômicos, servindo de importante auxílio aos intérpretes e legisladores, quando diante de casos concretos, que exijam soluções coerentes.

Nesse sentido, a racionalidade limitada poderia justificar uma interpretação menos rigorosa do requisito da imprevisibilidade, já que se baseia na oportunidade e dever de prever, levando em consideração o custo de se adquirir informações e a própria limitação racional dos contraentes.

\subsubsection{Os COMPORTAMENTOS OPORTUNistas DOS CONTRAENTES}

A conduta oportunista dos agentes econômicos é outro fator estudado dentro da teoria do contrato incompleto, sendo, também, responsável pelos custos transacionais. Tal comportamento está associado ao ato de agir com malícia, egoísmo, não cooperação e reprovabilidade, a partir do qual o agente econômico ajusta as circunstâncias para atingir o benefício pessoal. Para Pinheiro (2010, p. 9), o oportunismo "deve ser definido como uma forma forte de busca do interesse próprio, que pode passar por práticas desonestas, incluindo mentir, trapacear e roubar”. Sobre o tema, Guerinoni (2007, p. 44) observa:

O oportunismo indica, por outro lado, uma propensão específica do homem a buscar, com astúcia, finalidades egoísticas. Por conta do oportunismo, as promessas não são espontaneamente cumpridas pelos agentes humanos: torna-se assim necessário prever salvaguardas visando ao cumprimento dos acordos. Se não existisse racionalidade limitada e oportunismo, muitos dos problemas que os contratos devem confrontar por conta da incerteza seriam notavelmente simplificados.

Agir de forma oportunista é recorrer a comportamentos estratégicos, seja em razão de uma das partes possuir uma informação privilegiada, seja pela impossibilidade de acesso à mesma informação pelo outro contratante. Cooter e Ulen (2010, p. 64) exemplificam:

Para ilustrar: ocorre muitas vezes que os vendedores sabem mais sobre a qualidade dos bens do que os compradores. Por exemplo, uma pessoa que coloca seu carro à venda sabe bem mais sobre suas peculiaridades do que um 
comprador em potencial. De modo semelhante, quando um banco apresenta um contrato de abertura de conta para ser assinado por uma pessoa que está abrindo uma conta corrente, o banco sabe muito mais do que o cliente sobre as consequências jurídicas do contrato. Quando os vendedores sabem mais a respeito de um produto do que os compradores, ou vice-versa, diz-se que as informações estão distribuídas assimetricamente no mercado.

Assim, "a presença de informação privada, inacessível a um ou a ambos os contratantes, permite que se recorra ao comportamento estratégico e representa um obstáculo à realização de trocas eficientes" (BELLANTUONO, 2000, p. 49).

Araújo (2007, p. 153) indica como solução comum para se enfrentar o problema do oportunismo ou do holdup, qual seja "a de se propor a realização de contratos minimalistas, com preço fixo e o menor número possível de estipulações - de acordo com o pressuposto de que, quanto maior a simplicidade, menos abundantes as armadilhas, e mais detectáveis". Da mesma forma, comportamentos cooperativos ajudariam a evitar situações de crises no relacionamento, já que as partes, diante de novas circunstâncias, entrariam em comum acordo para modificar os termos do contrato. Além disso, "o Direito pode certamente remediar as condutas oportunistas, considerando ilícitas a malícia ou a indução a erro com os quais um contratante desfruta da vantagem superveniente" (FICI, 2000, p. 97).

Um ordenamento jurídico fraco, se associado à conduta maliciosa, finda por provocar ineficiência contratual, pois "ninguém está disposto a concluir contratos nos quais a falta de sanções sociais ou de regras estatais adequadas torne especialmente elevado o risco de comportamentos oportunistas" (BELLANTUONO, 2005, p. 64). Assim, as normas estatais devem atuar como maiores incentivadoras para que os atores econômicos atuem no mercado de forma altruísta e cooperativa, devendo desestimular ações opostas. Segundo Cooter e Ulen (2010, p. 209), "fazendo cumprir a promessa, o tribunal pode dar a ambas as partes o que elas querem. Dar-lhes o que elas querem promove a troca e incentiva a cooperação reduzindo a incerteza e o risco". Sendo assim, "a primeira finalidade do direito contratual é possibilitar que as pessoas convertam jogos com soluções ineficientes em jogos com soluções eficientes" (COOTER; ULEN, 2010, p. 211).

Em verdade, os recentes estudos jurídico-econômicos demonstram que as convenções sociais influenciam o comportamento humano, possibilitando uma postura que não leva em consideração apenas o interesse particular, mas passe a adotar outras motivações, tais como: o altruísmo, a preocupação pelo interesse geral ou o bem comum, o sentimento de justiça, a solidariedade e a equidade. Acrescenta-se, ainda, que "a vontade de salvaguardar a própria reputação constitui - observadas determinadas condições, um desincentivo a adotar comportamentos oportunistas e um fator de adimplemento espontâneo dos contratos" (FICI, 2005, p. 99). 
É que a má reputação, considerada como um custo à parte que deva ser levado em conta quando tiver perseguindo o próprio interesse, reduz as perspectivas de futuras transações. Assim, o agente econômico racional deve observar os custos existentes ao agir de forma cativa, optando, se desfruta ou não, da posição contratual de vantagem, eventualmente produto da modificação de circunstâncias. Ao abordar o tema, Fici (2005, p. 99) escreve:

Entre os custos futuros de uma determinada conduta oportunista inclui-se não apenas, obviamente, o custo derivado da interrupção da relação e assim da perda (eventual) de investimentos específicos nessa relação, mas também os custos futuros derivados da perda reputacional em confronto com a parte considerada vítima de abuso, ou com outros eventuais parceiros negociais.

O receio da parte em perder a reputação configura um impedimento à realização de uma conduta oportunista. Em especial, isso ocorre nas relações de longa duração, já que, ao contrário dos acordos isolados, exigem que as partes atuem com cooperação, do contrário "perder-se-ia a possibilidade de efetuar outros negócios posteriores com o agente enganado, ou com outros, tão logo se disseminasse a informação de sua inconfiabilidade" (FICI, 2005, p. 100). Baseando-se na doutrina econômica da teoria dos jogos, ${ }^{11}$ Fici (2005, p. 100) prossegue afirmando que, "a melhor estratégia para o jogador é, assim, convencer o outro de sua própria honestidade, e respeitar, a cada negócio, a confiança em si depositada.”

Nesse sentido, tem-se que o agente, em cada transação realizada, buscará adimplir as suas obrigações a fim de encorajar as futuras contrapartes a nele confiar ou, em outras palavras, manter a própria reputação de honestidade. Sztjan (2010, p. 14) exemplifica que "no comércio internacional a confiança serve de fundamento para que muitos empresários aceitem a estranha prática de empregar termos genéricos”. Acrescenta, também, que a "maximização da eficiência permite que, agindo racionalmente, celebrem contratos incompletos desde que conheçam as políticas econômico-sociais que poderão ser invocadas em face de uma dada operação internacional". Na hipótese, "a incompletude dos contratos poderia constituir-se na estratégia preferidas dos contratantes que pretendem basear, na confiança mútua, a função de assegurar o respeito às obrigações assumidas" (FICI, 2005, p. 101), afastando, assim, a presença de condutas oportunistas.

\subsubsection{As InCERTEZAS DOS NEgócios JURÍdicos}

A incerteza é apontada como um dos fatores objetivos para a existência dos custos de transação nas operações econômicas. Isso ocorre porque nem sempre será certo o resultado previsto pela atividade negocial, uma vez que algumas operações são caracterizadas 
pela incerteza dos resultados. Fici (2005, p. 77) explica que, nesse quadro, "os contratantes não podem conhecer com exatidão os resultados. A satisfação de suas expectativas é condicionada a acontecimentos não controláveis".

O mesmo autor adverte que a incerteza não deve ser compreendida apenas pelos fatores comuns de risco, conhecidos pela doutrina interna, como caso fortuito, força maior e fato do príncipe. A tais hipóteses, adicionam-se os eventos futuros não controláveis e não calculáveis pelas partes (incerteza primária) e os comportamentos que os contraentes têm no curso da execução do contrato. Essa (incerteza secundária) é gerada pela possibilidade de uma parte se comportar estrategicamente no confronto com a outra (FICI, 2005, p. 77). Esse comportamento estratégico é decorrente de uma natural predisposição de qualquer uma das partes ter uma atitude oportunista, visando a atingir os seus próprios interesses.

De igual modo, Guerinoni (2007, p. 47) classifica incerteza primária como "aquela que diz respeito aos eventos futuros não controláveis pelas partes, que fogem à sua capacidade de previsão." E incerteza secundária como aquela que "se refere à possibilidade dos contratantes se comportarem estrategicamente com relação ao outro no curso da execução do contrato”. Tendo em vista a presença do elemento incerteza, a gestão de uma operação econômica de longa duração torna-se complexa e custosa.

Em um mundo ideal, a incerteza seria afastada pela capacidade ilimitada que cada contraente se disporia a prever e se programar a respeito de todas as circunstâncias modificadoras do contrato. Porém, conforme adverte Fici (2007, p. 78), trata-se de um cenário utópico, não possível, haja vista a capacidade cognitiva limitada dos contraentes e a presença dos custos elevados de previsão do futuro. Por essa razão, a resposta à incerteza não pode estar presente na redação de um contrato completo, mas o reconhecimento que o contrato pode ser deliberadamente incompleto pode constituir uma eficaz solução aos problemas gerados pela incerteza.

A incerteza é, portanto, um empecilho à gestão do contrato, tanto no momento em que as partes estão firmando a programação originária do acordo quanto na hipótese de uma eventual necessidade de adaptação em virtude de mudanças de circunstâncias. Conforme leciona Guerinoni (2007, p. 48), "em especial, se as transações fossem imunes a influências adversas externas, ou, ao menos, se essas pudessem ser previstas (e disciplinadas em seus efeitos), não existiria nem mesmo a necessidade de revisar os contratos”. É em razão das mudanças de circunstâncias que se manifesta a necessidade de modificação.

Como adverte Sztjan (2010, p. 3), as "mudanças das estruturas de mercados desequilibram ou tornam menos eficientes operações de longo prazo já em curso”. O elemento incerteza, muitas vezes, não é observado ou previsto pelos contratantes, porém, "se as partes pudessem prever o fato, provavelmente formulariam regras para ajustar a operação ao evento de forma a dar-lhe disciplina” (SZTJAN, 2010, p. 3). 
Outro fator objetivo da operação econômica a ser apreciado é a longa duração e a complexidade do negócio contratual.

\subsubsection{A LONGa DURAÇÃo E a COMPlexidade Do Negócio CONTRATUAL}

Todo negócio que se estende no tempo torna mais difícil a sua gestão, por estar mais sujeito às incertezas decorrentes das mudanças sociais e aos custos operacionais para a redação, conclusão e execução do acordo. Nesse sentido, Sztjan (2010, p. 15) pontua que "fatores ambientais, sistema jurídico, idioma em que o contrato tiver sido redigido, normas sociais observadas em certas comunidades provocam impactos na complexidade da redação do instrumento contratual que nem sempre são claras”. Por isso, para Roppo (1988), quanto mais um contrato é complexo, de longa duração, relacional, tanto mais é destinado a ser inevitavelmente incompleto.

Como já mencionado, “a incompletude é um problema que diz respeito a todos os contratos nos quais a execução não coincida com a conclusão, mas deva desenvolver-se em momento sucessivo" (FICI, 2005, p. 79), o que permite afirmar que qualquer contrato de execução não instantânea está sujeito ao risco da superveniência.

Observa-se, assim, que o tempo, elemento caracterizador do contrato, "é fruto de uma escolha precisa dos contratantes, cujo interesse, também duradouro, é voltado não a uma prestação, mas a uma execução conforme o cronograma previsto" (MARASCO, 2006, p. 21). De outro modo, Marasco (2006, p. 24) adverte que "o tempo é elemento capaz de alterar os termos do equilíbrio contratual, de impedir sua atuação e, assim, de frustrar as expectativas das partes”. A respeito, Rachel Sztjan (2010, p. 9) acrescenta:

Premissa é que, raramente, as circunstâncias ou o conjunto de fatos existentes e analisados no momento da contratação permanecerão constantes durante o tempo de execução do contrato; ainda que as pessoas prevejam ou intuam algumas possíveis mudanças, a previsão de regras que mantenham o equilíbrio e garantam a eficiência das alocações, para todas as situações, é difícil. Os efeitos que a passagem do tempo nas prestações de cada uma das partes difere, em comparação com as hipóteses em que a prestação seja adimplida imediatamente após a conclusão do contrato por uma das partes apenas, se ela for devida durante o prazo do contrato de forma continuada ou periódica (a execução consistirá em série de atos escalonados).

Verifica-se, portanto, que todo contrato possui uma dimensão temporal retratada, inicialmente, quando do surgimento do acordo, em seguida com o seu desenvolvimento, para depois, deixar de existir. Um acordo pode nascer e logo imediatamente extinguir-se, é o caso dos contratos de execução instantânea. No entanto, pode nascer e durar, nesse caso, tornando a relação mais complexa, motivo pelo qual se evidencia no 
estudo econômico uma ligação entre incompletude e duração do contrato. Quanto ao tempo, Fici (2005, p. 88-89) acrescenta:

A dimensão temporal pode, por outro lado, ser útil à satisfação de uma necessidade duradoura. Uma necessidade que não é suscetível de satisfação instantânea, mesmo que diferida. Nesta versão, o tempo constitui-se primordial e sua função é satisfazer continuamente, (ou periodicamente) um interesse duradouro. Assim considerado, o longo termo, sendo desejado pelas partes e satisfazendo um interesse duradouro, adquire relevância causal. O alongamento do adimplemento no tempo é, na verdade, condição indispensável para que o contrato produza os efeitos desejados pelas partes. Ainda, a utilidade que se obtém do contrato é proporcional à sua duração. O negócio é útil enquanto dura.

Detectado o problema da modificação de circunstâncias, a doutrina, inicialmente, formulou a denominada cláusula rebus sic stantibus, para indicar que "em todo contrato de prestações sucessivas, haverá sempre uma cláusula implícita de que a convenção não permanece em vigor se as coisas não permaneceram como eram no momento da celebração" (GAGLIANO; PAMPLONA FILHO, 2006, p. 267). Atualmente, esta ideia está presente no ordenamento vigente por meio da denominada teoria da imprevisão, apreciada na próxima parte.

Em conclusão, é certo que o fator tempo interfere no andamento da relação contratual, sendo inerente aos contratos não instantâneos o problema de incompletude econômica e de gestão da superveniência.

\subsubsection{Os investimentos EM ATivos específicos}

Os investimentos em ativos específicos, assim como os fatores retromencionados (racionalidade limitada, oportunismo, incerteza, complexidade e tempo), são também responsáveis pela incompletude do contrato. Os investimentos específicos são gastos realizados pelos agentes econômicos em uma determinada relação contratual, aproveitáveis somente a uma dada operação, a qual teria a sua produtividade prejudicada se os investimentos forem transferidos para outra atividade. Pinheiro (2010, p. 10) esclarece:

Por exemplo, um trem de alta velocidade será de pouca utilidade se utilizado em outra via férrea que não tenha recebido o tratamento adequado para acomodá-lo. Todo o conhecimento acumulado por um funcionário sobre as pessoas e a cultura de uma empresa será perdido se ele trocar de emprego. O mesmo se aplica ao conhecimento acumulado por um fornecedor sobre as exigências técnicas e gerenciais de um grande cliente. O tamanho dessa 
perda vai depender de como foi criado o ativo; se ele foi desenvolvido especificamente para amoldar-se a uma determinada transação, a perda com a mudança de uso tende a ser grande.

Os doutrinadores econômicos sugerem, como uma forma de salvaguardar os investimentos específicos presentes em uma operação econômica, que as partes adotem um modelo contratual duradouro. Nesse sentido, “a conclusão dos contratos de longo termo assegura que o contrato dure ao menos o tempo necessário para recuperar o investimento efetuado em vista ou em razão da conclusão do próprio contrato” (FICI, 2005, p. 90), afastando, assim, a possibilidade dos agentes econômicos comportarem com oportunismo.

Pretende-se evitar com a formulação de um contrato de longo termo, cujos investimentos específicos não foram ainda recuperados e que uma das partes, em regra, a que não aplicou receitas em ativos, não renove o acordo. Outra situação é quando os acordos de investimentos específicos são efetuados por ambos os contraentes, menos sujeitos a uma conduta oportunista. Atento a este ponto, Fici (2005, p. 104) acrescenta:

Se os investimentos específicos não são bilaterais, ou seja, efetuado por ambos os contratantes, ou se os investimentos específicos realizados por um dos contratantes são consideravelmente maiores que aqueles realizados pelo outro, a operação torna-se crítica para aquele contratante que fez maiores investimentos, vez que se encontra exposto a risco, especialmente quando as circunstâncias do negócio mudam, em um possível abuso da outra parte, ou seja, o pedido oportunista de renegociação do conteúdo do contrato”.

Quando os investimentos específicos são realizados por apenas um dos contraentes, este desejará dar continuidade ao acordo, porém estará em uma posição de maior fragilidade, podendo ser surpreendido com um pedido oportunista de renegociação dos termos contratuais. Atentando-se, portanto, à racionalidade limitada, à possibilidade de oportunismo e à presença de ativos específicos, quando a segurança jurídica se torna "essencial para fomentar o investimento e a eficiência econômica" (PINHEIRO, 2010, p. 9). Conforme adverte Fici (2005, p. 105):

Se os investimentos específicos não fossem tutelados, agentes racionais seriam desincentivados a fazer tais investimentos ou o fariam em menor porte, o que é um resultado ineficiente. Eis por que torna-se importante que o ordenamento jurídico se preocupe em disciplinar de modo especial as operações econômicas estruturadas com investimentos específicos, tutelando a parte mais fraca exatamente em razão dos investimentos efetuados para aquela operação econômica. 
Verifica-se, portanto, que os fatores subjetivos, oportunismo e racionalidade limitada, atuam diretamente sobre o fator objetivo do investimento em ativos específicos. Os agentes econômicos podem ter receio de firmar um negócio, aparentemente lucrativo às partes e quando o acordo vincula a necessidade de investimento em ativos específicos por apenas um contraente. "Se este problema não for resolvido, ele pode levar a um severo nível de subinvestimento, pois a parte que tiver de investir vai olhar para a frente e reconhecer que o retorno esperado no investimento pode ser expropriado pela outra parte” (PINHEIRO, 2010, p. 10).

Diante deste quadro de incerteza, a parte mais vulnerável buscará prever todas as possíveis contingências futuras, definindo "remédios" e ações para cada estado. "Mas a condição de racionalidade limitada inviabiliza essa ação, fazendo com que subsistam lacunas contratuais" (PINHEIRO, 2010, p. 10). Assim, mesmo que a parte procure realizar um contrato completo, os fatores ensejadores dos custos de transação acabam por vedar tal objetivo. A presença de um ordenamento jurídico atuante será indispensável para combater condutas oportunistas, motivo pelo qual na próxima parte se examinará a aplicação da teoria econômica do contrato incompleto pela ordem jurídica.

\section{Fundamentos eConômicos de ReVisão CONTRATUAL}

Discute-se a aplicação dessa nova forma de visualizar o instituto contratual. Para tanto, inicia-se esta última parte com uma breve contextualização histórica do contrato, atingindo a atual hipótese de revisão, baseada na teoria da imprevisão. Por fim, pretende-se demonstrar que os fundamentos econômicos do contrato incompleto ampliam a hipótese revisional presente no ordenamento jurídico, fazendo os estudos desenvolvidos por economistas inovarem a ordem jurídica.

\section{I TEORIA DA IMPREVISÃO}

No presente tópico, pretende-se apresentar os principais aspectos envolvendo a teoria da imprevisão, ${ }^{12}$ atualmente, utilizada para fundamentar as decisões prolatadas pelos órgãos do Judiciário quando da realização de revisão em contratos de longa duração.

A abordagem não terá a pretensão de esgotar possíveis discussões doutrinárias existentes, nem tão pouco será utilizada para destrinchar conceitos já trabalhados em obras de conceituados doutrinadores, ${ }^{13}$ especialistas da área contratualista. Busca-se, entretanto, realizar uma explanação da teoria adotada pelos juristas brasileiros, a fim de que se possa realizar no próximo item um contraponto com a teoria econômica do contrato incompleto, que tem o condão de alargar a vigente hipótese revisional, baseada na teoria da imprevisão. Sobre isso, Pinheiro e Saddi (2005, p. 117) advertem:

O nosso sistema jurídico - e, em particular; o novo Código Civil, apenas para darmos um exemplo - esgotou em dois ou três institutos a hipótese 
do "preenchimento" dos contratos incompletos: a imprevisão (artigo 317), a onerosidade excessiva (artigo 478) e a lesão grave (artigo 157), todos tendo como pressuposto a boa-fé objetiva. O que se pretende é oferecer a possibilidade de remediar a previsão defeituosa com a correção de qualquer evento externo à economia do contrato.

Toda ideia que circunda ou deveria nortear uma revisional de acordos livremente pactuados tem a intenção de alcançar o reequilíbrio do vínculo contratual, ou seja, intenta-se remanejar as partes para manter a situação de proporcionalidade perante as suas prestações. Conforme esclarece Lisboa (2010, p. 119):

A desproporção superveniente da relação contratual é possível nos contratos de trato sucessivo ou de execução continuada, que são negócios jurídicos cuja execução se prolonga no tempo. Nesses casos, fala-se vulgarmente em contrato a prazo, porque as obrigações assumidas pelas partes são fracionadas em prestações ou, ainda, porque foram postergadas até o evento contratualmente ajustado (obrigações sob condição ou a termo). Tal fenômeno pode, ainda, verificar-se em negócios jurídicos de prazo indeterminado (como na locação de coisa), assim como nos contratos cativos de longa duração, em que uma das partes subordina-se quase que vitaliciamente à predisposição do conteúdo estabelecido pela outra (como é o caso do plano de saúde).

A teoria da imprevisão, disciplinada nos arts. 478 a 480 do Código Civil de 2002, incide, portanto, sobre os contratos de longo termo (execução diferida ou continuada), já que sobre os instantâneos (execução imediata) não há a possibilidade de ocorrência de desequilíbrio posterior. Relativiza-se a vinculatividade contratual ${ }^{14}$ buscando ajustar a situação do contratante desfavorecido pelo decurso do tempo, quando diante da ocorrência de acontecimentos imprevisíveis capazes de alterar radicalmente a sua condição econômica. Por imprevisível, considera-se "tudo aquilo não passível de previsão, tudo o que não fizesse parte do cotidiano do homem comum e que, se cogitado no instante vinculativo, por certo seria causa impeditiva da contratação” (BORGES, 2006, p. 90).

Percebe-se, portanto, que o legislador não afastou por completo a regra a qual "o contrato tem força de lei”, pois é perfeitamente aplicável aos contratos de execução imediata. Porém "exigir a la letra, el contrato que fue (y ya no lo es) es abusar del contrato", motivo pelo qual "la incorporación en ese mismo contrato, desde su conformación, de una cláusula de renegociación es precaución que se impone como la más conveniente y previsora" (MORELLO, 1994, p. 62). Comentando os arts. 1.372 e 1.467 do Código Civil Italiano, utilizados como referencial pelo legislador brasileiro, Marasco (2006, p. 8) afirma: 
O confronto das duas normas permite fazer uma primeira consideração, a saber, que a regra "o contrato tem força de lei”, na sua acepção restrita e literal, diz respeito essencialmente aos contratos de execução imediata; para os contratos de execução prolongada, a sua aplicação dá-se na medida em que seja compatível com a causa e com a função que esse contrato persiga. Se a isso se acrescentar que no fundamento do artigo 1372 c.c. existe uma exigência de estabilidade e de certeza na relação negocial, pode-se concluir que apenas aparentemente o princípio pacta sunt servanda é conflitante com a regra que atribui relevância às circunstâncias que modificam o equilíbrio contratual, e com o princípio da revisão contratual. Os remédios que o ordenamento reconhece para se reagir às mudanças no cenário no qual o contrato se concluiu (resolução e revisão) não afetam a natureza vinculante do contrato, mas, ao contrário, eliminam (reestabelecendo aos termos originais) termos diversos daqueles que as partes desejaram, confirmando assim o princípio determinado no art. 1372 c.c.

Pela orientação desenvolvida na teoria da imprevisão, o Judiciário não apenas pode resolver um contrato, mas também deve atuar como poder estimulador da continuidade da relação jurídica, no momento em que rever as cláusulas contratuais. Perfilhando tal entendimento, Morello (1994, p. 63-64) acrescenta:

Debe darse el máximo de chance al ejercicio de la acción de revisión porque por encima de todas las razones esgrimidas para justificarlo (y lejos de apontocarse en un rígido e insensible apego a una mal entendida aplicación de la autonomía de la voluntad negocial), esa acción es la que efectivamente defiende al contrato sin desperñarlo en una resolución carente de sentido, y que las partes no atinan normalmente a demandar. Porque al ceñirse a los dos extremos cerrados (inmodificable mantenimiento del contrato $a b$ origine/resolución) dejan al juez sin margen de maniobra para componer, equitativamente, el sinalagma. Con lo cual se consuma la máxima inseguridad jurídica, cual es la de consagrar una solución injusta, cuando aquélla — la justa y equitativaera posible de obtenerse, sin embargo, a través de una manera más razonable y económicamente más conveniente, de una flexible y prudente (discreta) interpretación del sistema legal.

Como intérprete da lei, o Poder Judiciário, por meio do Superior Tribunal de Justiça, órgão competente para examinar os dispositivos do Código Civil, tem advertido:

É requisito para a aplicação da teoria da imprevisão, com o restabelecimento do equilíbrio econômico-financeiro do contrato, que o fato seja imprevisível quanto à sua ocorrência ou quanto às suas consequências; estranho à 
vontade das partes; inevitável e causa de desequilíbrio muito grande no contrato. (REsp 1.129.738/SP, Rel. Ministro Mauro Campbell Marques, Segunda Turma, julgado em 05/10/2010, DJe 21/10/2010)

Assim, quando diante de circunstâncias capazes de tornar as obrigações firmadas pelas partes impossíveis de cumprimento ou de sacrifício exorbitante a um dos contratantes, o magistrado deve optar pela revisão contratual em vez da resolução do contrato, procurando conservar o negócio jurídico. ${ }^{15}$ Consoante Orlando Gomes (2008, p. 216):

O art. 478 do Código Civil deve ser interpretado à luz do princípio da conservação dos negócios jurídicos, pelo qual se deve procurar conservar o máximo possível do negócio jurídico realizado, tanto no que diz respeito à sua existência quanto à sua validade e eficácia.

Em resumo, Bittar Filho (2002, p. 121) assinala que, no direito brasileiro, os pressupostos de admissibilidade da teoria da imprevisão são:

a) O contrato não deve haver sido totalmente executado (uma prestação, ao menos, tem de estar ainda pendente); b) o acontecimento deve ser imprevisível, anormal e exógeno (incomum, anormal e estranho à vontade das partes); c) deve haver onerosidade excessiva para um dos contratantes e benefício exagerado para outro; d) há de ocorrer a alteração radical das condições econômicas no momento da execução do contrato, em confronto com as do instante de sua formação; e) deve inexistir a mora antes do acontecimento.

Tendo como objeto as ações revisionais de acordos de longo termo, o Superior Tribunal de Justiça colocou em pauta a discussão envolvendo os contratos de arrendamento mercantil, que previam reajuste das prestações com base na variação da cotação de moeda estrangeira. O episódio resultante de inúmeros processos judiciais ocorreu em janeiro de 1999, com a forte desvalorização do real frente à moeda norte-americana, tendo sido relatado pelo Ministro Antônio de Pádua Ribeiro como um "evento objetivo e inesperado, a ensejar a modificação da cláusula contratual de ordem a evitar locupletamento de um contratante em detrimento do outro" (REsp 343.617/GO).

Na ocasião, a Corte Especial reconheceu a incidência do Código de Defesa do Consumidor (Lei n. 8.078/90), nos termos do art. $6^{\circ}$, V, em virtude da constatação "de fato superveniente ao pacto celebrado, consubstanciado, no caso, por aumento repentino e substancialmente elevado do dólar, situação de onerosidade excessiva para o consumidor 
que tomou o financiamento" (REsp 473.140/SP, julgado em 12/02/2003, DJ 04/08/2003, p. 217).

Nesse julgamento, contudo, o Tribunal Superior, por decisão não unânime, repartiu o ônus advindo da elevação acentuada da cotação da moeda norte-americana, tendo o Ministro Aldir Passarinho Junior proposto, in verbis:

[...] Índice de reajuste repartido, a partir de 19.01.99 inclusive, eqüitativamente, pela metade, entre as partes contratantes, mantida a higidez legal da cláusula, decotado, tão somente, o excesso que tornava insuportável ao devedor o adimplemento da obrigação, evitando-se, de outro lado, a total transferência dos ônus ao credor, igualmente prejudicado pelo fato econômico ocorrido e também alheio à sua vontade. $[\ldots]$.

Na hipótese apresentada, verificou-se o problema da interpretação realizada por um terceiro à operação, ainda que judicial. Muitas vezes, "a intervenção judicial acaba por facilitar ou favorecer comportamentos oportunistas" (SZTAJN, 2005, p. 40). Sobre a discussão dos contratos de leasing, Rachel Sztajn (2005, p. 40) recorda:

Sem atentar para o fato de que o risco de eventual variação extraordinária do câmbio fora aceito pelos consumidores em troca de uma taxa de juros menor que as praticadas no mercado quando os contratos eram ajustados em moeda corrente, as decisões favoráveis aos demandantes consumidores foram causa do desaparecimento do leasing no país, com o quê, no médio prazo, a sociedade perdeu bem-estar.

Outro tema objeto de revisão judicial, com base no art. 421 do Código Civil, foi o contrato de compra de soja por agricultores à industria, tendo também gerado efeitos que o próprio Judiciário inicialmente não pode prever.

A variação para mais no preço da soja e derivados, que não foi dividida com os produtores, e a invocação da "função social do contrato" deram causa a sentenças que resolveram operações contratadas antes do evento variação de preço. E, como efeito de segunda ordem, o fato de que a quebra da relação de confiança entre produtores e indústria fez cessar práticas como a antecipação, por conta do preço a ser pago ao final, de fornecimento pela indústria, aos agricultores, de sementes, adubo, defensivos ou outros insumos. Resultado foi o endividamento frente ao sistema financeiro, com o quê o risco, que antes era dividido entre industrial e produtor, recaiu inteiramente sobre o último. O legislador 
não pretendia tal efeito. Mas, como não há normas que possam afastar a incidência desse art. 421 das operações interempresariais, assumiu o risco dos efeitos de uma regra mal-projetada e pior aplicada. (SZTAJN, 2005, p. 40)

Apesar do Superior Tribunal de Justiça, em momento posterior, ter modificado as decisões proferidas no sentido de aplicar a Teoria da Imprevisão aos contratos de compra de soja, os efeitos oriundos delas já haviam se manifestado nas relações econômicas. Em recente julgado, a Corte Especial, assim, decidiu:

DIREITO CIVIL E COMERCIAL. COMPRA DE SAFRA FUTURA DE SOJA. ELEVAÇÃO DO PREÇO DO PRODUTO. TEORIA DA IMPREVISÃO. INAPLICABILIDADE. ONEROSIDADE EXCESSIVA. INOCORRÊNCIA. 1. A cláusula rebus sic stantibus permite a inexecução de contrato comutativo - de trato sucessivo ou de execução diferida - se as bases fáticas sobre as quais se ergueu a avença alterarem-se, posteriormente, em razão de acontecimentos extraordinários, desconexos com os riscos ínsitos à prestação subjacente. 2. Nesse passo, em regra, é inaplicável a contrato de compra futura de soja a teoria da imprevisão, porquanto o produto vendido, cuja entrega foi diferida a um curto espaço de tempo, possui cotação em bolsa de valores e a flutuação diária do preço é inerente ao negócio entabulado. 3. A variação do preço da saca da soja ocorrida após a celebração do contrato não se consubstancia acontecimento extraordinário e imprevisível, inapto, portanto, à revisão da obrigação com fundamento em alteração das bases contratuais. 4. Ademais, a venda antecipada da soja garante a aferição de lucros razoáveis, previamente identificáveis, tornando o contrato infenso a quedas abruptas no preço do produto. Em realidade, não se pode falar em onerosidade excessiva, tampouco em prejuízo para o vendedor, mas tão-somente em percepção de um lucro aquém daquele que teria, caso a venda se aperfeiçoasse em momento futuro. 5. Recurso especial conhecido e provido. (REsp 849.228/GO, Rel. Ministro Luis Felipe Salomão, Quarta Turma, julgado em 03/08/2010, DJe $12 / 08 / 2010$ )

Tendo em vista o impacto que essas decisões causam na economia é que as ações revisionais devem ser examinadas com a devida cautela, afastando, assim, a manifestação de comportamentos oportunistas, que, com o amparo da lei, desejam descumprir os acordos voluntariamente pactuados.

Aplica-se, portanto, a teoria da imprevisão em casos especialíssimos para buscar reequilibrar o contrato que sofreu ou vem sofrendo interferência de evento superveniente, "aquele cujos efeitos são posteriores à data de conclusão do negócio jurídico e, por refletirem sobre a relação contratual, são de interesse das partes” (LISBOA, 2010, p. 123). Como aludido, o Código Civil (arts. 478 a 480) adota norma prevista 
na lei civilista italiana (arts. $1.467^{16}$ e $1.468^{17}$ ), que também faz referência à excessiva onerosidade superveniente, outorgando aos magistrados rescindir ou revisar o contrato, aplicando, ao caso concreto, o princípio do equilíbrio econômico do contrato.

A aplicação da teoria da imprevisão e, por conseguinte, a revisão judicial estão vinculadas à ocorrência de uma onerosidade objetivamente excessiva (aplicável a qualquer pessoa) e à extrema vantagem da outra parte. Vale ressaltar, ainda, que a onerosidade decorre de acontecimentos extraordinários e imprevisíveis, afetos aos contratos de longa duração (GOMES, 2008, p. 216).

\subsection{AplicaÇÃo da teoria eCONÔMica do CONTrato INCOMPLETO NO ORDENAMENTO JURÍDICO}

Feitas as breves colocações a respeito do vigente quadro normativo, almeja-se neste último tópico inserir na teoria jurídica os conhecimentos assimilados da teoria econômica do contrato incompleto, estudada na segunda parte. Inicia-se a abordagem com a compreensão de que o contrato incompleto é um meio alternativo de gerir riscos supervenientes, cujas características são distintas daquelas reconhecidas pela teoria da imprevisão. Visto o contrato dessa forma, reconhece-se, portanto, uma ampliação da hipótese de revisão contratual.

Os contratos incompletos partem da premissa de que as partes podem optar em não dispor sobre um determinado evento futuro, seja ele previsível ou imprevisível, preferindo fazê-lo, se necessário, em momento posterior. Por este motivo, a Teoria da Imprevisão ou a onerosidade excessiva "não se constituem em métodos adequados para identificar contratos com essa característica. Mais do que isso, não apresentam formas de superar a incompletude contratual sem ter de renegociar ou discutí-lo $a b$ initio" (PINHEIRO; SADDI, 2005, p. 118).

Não restam dúvidas, toda relação contratual, cuja execução não é imediata, mas sim diferida ou continuada, poderá vir a sofrer possíveis modificações nas contingências originariamente previstas. Porém, a observação que se pretende fazer ao introduzir na órbita jurídica uma teoria econômica é que não apenas com base na imprevisão será permitido rever acordos contratuais.

Em verdade, a partir da escola Law and Economics e, em especial, dos estudos apresentados por Ronald Coase, é que os economistas começaram a disseminar pensamentos que teriam reflexos substanciais na esfera jurídica. Dentre esses, no que tange a relação contratual e o mercado, identifica-se os custos de transação.

Após os estudos dos custos de transação, os contratos bilaterais ou plurilaterais de longa duração passam a ser vistos como incompletos "porque os custos de transação proíbem as partes de colocarem todas as obrigações relevantes, isto é, maximizadoras de valor, no contrato" (POSNER, 2010, p. 50). Como visto, toda relação que se estende no tempo está sujeita aos custos de transação, isso ocorre, pois, a própria duração e complexidade do acordo são fatores geradores de tais custos. Ademais, a 
teoria do contrato incompleto reconhece a racionalidade limitada e a conduta oportunista das partes envolvidas nas relações negociais duradouras. Sustenta-se, em razão disso, que deve sempre haver uma cooperação entre os contraentes se diante da ocorrência de uma contingência inicialmente não prevista.

Assim, diante da complexidade das operações que se prolongam no tempo, pode ser aconselhável às partes não dispor ex ante sobre possíveis contingências, pois o fazendo estariam agregando, já na conclusão do acordo, um custo que poderá ser de forma mais eficiente alocado ex post, quando de sua efetiva ocorrência, por meio de uma conduta cooperativa recíproca. Deseja-se afirmar, com isso, é que, sabendo da incompletude contratual existente nas relações complexas de longa duração, é dispendioso tentar amarrar todas as contingências futuras, por isso é necessário reconhecer o direito das partes de fazê-lo em momento posterior. Evita-se, portanto, o emprego de recursos para melhor delimitar acordos do tipo.

Em verdade, os custos de transação condicionam as escolhas das partes, delimitam as suas alternativas. Dessa forma, os contratantes firmarão determinado acordo, a depender dos recursos necessários para negociá-lo, executá-lo e controlá-lo.

Reconhece-se, entretanto, que os tradicionais operadores civilistas, codificadores e textuais têm dificuldade de assimilar o contrato incompleto, recorrendo sempre às normas supletivas ou à aplicação da cláusula da imprevisão. Nesse sentido, Rachel Sztjan (2010, p. 23) leciona:

O operador do Direito, formado na tradição da dogmática civilista, de forte influência alemã, partindo das grandes codificações do século XIX, não se compadece com a noção econômica de contrato incompleto que é, para ele, inadmissível. Quando faltam disposições positivadas para o contrato típico, recorre-se às normas supletivas; se evento futuro, imprevisto ou imprevisível altera o sinalagma genético, o remédio é a aplicação da cláusula da imprevisão (rebus sic stantibus).

Tradicionalmente os civilistas compreendem os institutos da integração e da interpretação como instrumentos disponíveis a esvaziar qualquer alegação de incompletude contratual, pois mesmo que as situações da natureza mudem, ainda, sim, haverá o meio judicial para completá-los. Essas hipóteses, contudo, não abarcam as lacunas deliberadas, a existir por vontade das partes, e se destinam a estimular os contratantes a uma negociação futura. A incompletude deliberada permite que "cada parte decida, de maneira ótima, em relação a cada evento, tornando mais eficientes as alocações de recursos" (SZTJAN, 2010, p. 26).

Assim, na presença de um contrato deliberadamente incompleto, por meio do qual as partes optam por deixar uma lacuna no contrato a ser gerida posteriormente, deve-se afastar a aplicação dos mecanismos judiciais de integração e interpretação. 
Sendo o magistrado um terceiro à relação firmada e, em razão disso, detentor de informações assimétricas. Sua intervenção pode acarretar alocações indevidas e desestimuladoras de novas operações entre as partes.

Por ser o contrato deliberadamente incompleto uma estratégia contratual das partes, é imperioso aos juristas reconhecer que não é toda ocorrência de circunstâncias supervenientes e imprevisíveis a ensejar a aplicação da teoria da imprevisão. Deve-se atentar se as partes optaram por gerir possíveis contingências ex post, objetivando, com isso, evitar o emprego de custos ex ante. Muitas vezes, as partes de um contrato "podem economizar custos de transação deixando lacunas nele" (COOTER; ULEN, 2010, p. 225).

Um dos campos de grande aceitabilidade dos pressupostos da teoria econômica do contrato incompleto é o do comércio internacional. Isso ocorre em virtude da complexidade dos acordos firmados nesse âmbito, em especial, as atividades exportadoras, que permitem uma melhora no desenvolvimento do país, ao inserir moeda estrangeira no mercado interno.

Para exportar, são realizados "vários investimentos em ativos específicos; é necessário conhecer o mercado destino, adaptar os produtos e práticas comerciais às normas e costumes locais, aprender línguas, estabelecer relações pessoais, fixar o conhecimento da marca" (PINHEIRO, 2010, p. 18) etc. É necessário, portanto, a realização de elevados investimentos, que se transformam em incertezas e, por conseguinte, em custos de transação, principalmente, quando a segurança jurídica não se faz presente no mercado de investimento. Assim, "a qualidade do Judiciário, quando existem ou se manifestam vieses ideológicos, é outro fator de desestabilização e desincentivo a investimentos estrangeiros" (SZTJAN, 2010, p. 20).

Apropria-se, nesse estudo, dos contratos internacionais, por serem exemplos da versatilidade do mercado, da rotatividade de produtos e dos avanços tecnológicos. Em acordos do tipo, reconhece-se a correlação entre lacunas deliberadas, racionalidade limitada e custos de transação. Sobre isso, atenta-se, por serem pertinentes, para os questionamentos formulados por Rachel Sztjan (2010, p. 20-22):

Como então padronizar contratos de produtos em um mercado volátil? Como fixar padrões relativamente a bens inexistentes? O preço de novos produtos que venham a substituir, com mais qualidade, tecnologia de melhor qualidade, será igual ao dos atuais? Como prever, no clausulado contratual, salvo a negociação futura, a continuidade do fornecimento? Que padrão doméstico será definido para o novo produto? [...] Qual a garantia para fazer investimentos se a relação preço/qualidade estimada não for constante? Seria mais simples contratar com margem de flexibilidade e estabelecer-se que, futuramente, as partes renegociarão ou negociarão de forma a que os ganhos da operação sejam repartidos de maneira equitativa? 
A própria autora responde: "trata-se de riscos cuja previsão ex ante pode ser ineficiente ex post, razão pela qual se prefere deixar lacunas para preenchimento se e quando o novo produto vier ao mercado" (SZTJAN, 2010, p. 20). Reconhecendo-se, portanto, que o indivíduo possui racionalidade limitada e delimitar todas as contingências futuras só elevaria os custos de uma transação, as partes podem deliberar em deixar lacunas para serem preenchidas posteriormente. Está-se diante de uma correlação de fatores que, segundo os institucionalistas, fará os contratantes buscarem restabelecer os laços de confiança, voltarem a olhar e analisar os "usos e costumes de praças, aqueles criados e respeitados em alguns setores da atividade econômica, a repetição de operações entre mesmos agentes" (SZTJAN, 2010, p. 21).

Diante da incapacidade de se impedir a concretização de contingências, qual contrato deve ser aplicado? Rígido ou flexível? O sistema jurídico está apto a incentivar a cooperação entre as partes e o equilíbrio do acordo?

Em verdade, tem-se que a incompletude serve às partes para introduzir na relação aquela flexibilidade necessária para que o contrato possa continuamente adequarse às mudanças das circunstâncias, por isso reconhece-se que o contrato incompleto é um meio alternativo de gerir situações supervenientes. Ademais, consoante lição de Antonio Fici (2005, p. 114) “a incompletude é, assim, necessária para evitar os altos custos de transação que seriam gerados na tentativa de prever completamente o futuro, ou seja, todas as possíveis circunstâncias, no momento da conclusão do contrato.”

Diante dos riscos ao redor das operações complexas de longa duração e, também, dos elevados custos que transações dessa espécie podem conduzir, a teoria dos contratos incompletos prega a cooperação das partes, o que implica lidar com lacunas e imperfeições contratuais. Nesse sentido, Sztjan (2010, p. 23) afirma:

A percepção de que existe risco na operação deve ser acompanhada de propostas de solução inovadoras, sobretudo porque em operações complexas as regras predispostas ex ante nem sempre são suficientes. Simplicidade, equidade, confiança, desincentivo a oportunismos, presentes nas negociações e espelhados nos instrumentos de contrato permitem lacunas e negociação ex post eficientes.

O contrato relacional se enquadra nessa nova forma de ver o clausulado incompleto, por não compreender apenas uma troca simples, instantânea ou descontínua ${ }^{18}$ (discrete contracts), mas envolver uma verdadeira relação entre os contraentes. Se pela transação isolada as partes buscam especificar o objeto da respectiva prestação, o preço de um lado e o bem ou o serviço trocado de outro intentam antecipar cada possível eventualidade e seus efeitos; na troca relacional, o objeto não é facilmente especificado, eis que "as partes não manifestam a intenção de definir acuradamente o valor dos negócios que contrataram entre si no futuro”. (FICI, 2005, p. 113). 
O que se tem são contratos com mais partes integrando a relação e mais abertos a futuras participações. Ao contrário da troca isolada, cujo início e o fim são bem definidos, a duração de um contrato relacional não está previamente estipulada, ou seja, não é possível individualizar com clareza um momento inicial e um momento final. Além disso, eventuais conflitos que possam surgir no futuro devem ser sanados com os dois elementos que animam as partes de um relational contract, cooperação e solidariedade. Macedo Junior (2010, p. 7) aponta as principais diferenças entre os contratos relacionais e os contratos descontínuos:

Em primeiro lugar, é impossível especificar completamente o contrato relacional de longa duração em termos de preço, quantidade, qualidade e entrega, dada a sua mutabilidade constante. Isto porquanto ele envolve elementos não facilmente mensuráveis e visa regular situações que demandam alto grau de flexibilidade. Em segundo lugar, dadas as contínuas mudanças no produto ou características do serviço prestado, é impossível prever todas as contingências do futuro e especificar os termos dos ajustes nos contratos relacionais. [...]. Deste modo, os contratos relacionais fazem mais do que regular a troca de mercadorias e seu ajuste. Eles estabelecem o processo para cooperação inter organizacional no produto ou serviço, na produção e na estruturação da forma de gerenciamento. [...]. Por fim, os contratos relacionais de modo geral envolvem relações complexas entre diversas partes, nas quais os vínculos pessoais e de solidariedade, confiança e cooperação são determinantes.

Verifica-se, nesses contratos, que as partes escolhem em não assinalar definitivamente os riscos e benefícios entre si, optando em deixar os termos da troca cada vez mais abertos, sendo possível identificar uma conexão entre os contratos relacionais e os pressupostos da teoria econômica do contrato incompleto. Veja-se o que Fici (2005, p. 114) leciona:

Em uma relação, por outro lado, as partes procuram fixar também o procedimento que deverão seguir para dirimir eventuais conflitos que se verifiquem entre elas. Isso porque as disposições pactuadas são incompletas e é necessário, assim, constituir os meios pelos quais serão estabelecidos, no futuro, os termos do negócio. A incompletude serve às partes para introduzir flexibilidade na relação, sendo essa necessária para que o contrato possa continuamente adequar-se às mudanças das circunstâncias [...].

Conclui-se, portanto, que o contrato relacional não é apenas governado pela regra legal, mas também pela regra extra legal proveniente da mesma relação. Tais regras incentivam as partes a proceder corretamente na fase de execução do contrato, ainda 
mais se ocorrerem mudanças de circunstâncias. Compreende-se, assim, o contrato relacional como exemplo de contrato incompleto, porque as partes se utilizam de "remédios" extrajurídicos para sanear futuras contingências.

Tal situação diverge do modelo clássico ${ }^{19}$ do direito dos contratos, cuja edificação está na figura da transação isolada, pois nesse, o mecanismo utilizado pelas partes, quando o contrato não é adimplido nas condições previstas, é o legal, ou seja, socorre-se à disciplina legislativa da superveniência contratual, que se apresenta inoportuna aos contraentes se esses escolhem concluir um contrato incompleto.

Dessa forma, na presença de contratos deliberadamente incompletos o jurista deve incentivar os contraentes, quando da ocorrência de circunstâncias supervenientes, a adotar um clima de cooperação, gerindo ex post a contingência não prevista, em conformidade com a teoria do contrato incompleto.

\section{CONCLUSÃo}

Não é exagero dizer que todo contrato, ainda que de cunho eminentemente jurídico, tem consequências econômicas. De uma simples cláusula criada para proteger a parte vulnerável até a estipulação de pesadas multas em caso de descumprimento, os contratos se inserem diretamente na seara econômica.

É fato, quando um país tem um regime jurídico forte e respeitado, sua economia tende a crescer.

É esta a justificativa do trabalho ora apresentado, quando identifica a real impossibilidade de duas ciências, Direito e Economia, ainda se manterem reservadas uma em relação à outra, apesar das constantes investidas no sentido de encurtar essa distância, cujo caminho já tem um nome: análise econômica do Direito.

Ainda em meados do século XX, no berço das universidades americanas, a Teoria Econômica do Contrato Incompleto veio oferecer, sobretudo ao mundo jurídico, uma nova forma de ver a Teoria Geral do Contrato, em especial, os fundamentos da Teoria da Imprevisão para revisão de acordos contratuais de longo termo.

A existência dos custos de transação passou a ser questionada a partir da escola do Law and Economics e os princípios da Nova Economia Institucional, oferecendo uma nova visão à necessidade de um sopesamento entre fatores tais como os custos advindos da racionalidade limitada, comportamento oportunista, assimetria de informações, duração, investimentos em ativos específicos, complexidade e incerteza das relações contratuais. Essas circunstâncias sempre devem ser combatidas como forma de salvaguardar as partes de futuros prejuízos, mas, a partir da visão econômica, seu entendimento e consideração devem ser ampliados e entendidos como partidos necessários para a interação entre esses dois ramos da ciência, Direito e Economia.

De um lado, a justiça deve funcionar como principal fonte de salvaguarda ao reduzir incertezas e estabelecer uma estrutura estável para as relações contratuais. De outro, 
as consequências econômicas dessas garantias podem inviabilizar a plena eficácia e efetividade do contrato. O ponto de equilíbrio desses dois fatores é o que se busca.

A contribuição de Ronald Coase, com sua ideia de custo de transação, modificou o elenco das incertezas, entendendo-as como elementos necessários para assegurar a finalidade e os objetivos desses contratos, fundamentados na impossibilidade de antecipar todas as circunstâncias futuras. No entanto, deixar em aberto determinadas previsões contratuais e substituir os custos de transação por decisões administrativas entre empresas são elementos próprios das relações de longo prazo ou de execução diferida visando a evitar custos transacionais desnecessários.

A busca dessa justa medida, resultado da relação dialética, procurando um modelo capaz de satisfazer o mundo jurídico e a não onerosidade excessiva dos custos relacionados com fatos futuros passíveis ou não de acontecerem, conduziu este trabalho, pois a doutrina brasileira ainda não dispõe desses dispositivos, limitando-se unicamente a teoria da imprevisão como fundamento das ações revisionais levadas à apreciação do Poder Judiciário.

As operações econômicas e as operações jurídicas sempre existiram na sociedade, mas a importância dessas duas vertentes em sua completude e caracterizadas na figura dos contratos são fruto do aumento da relevância das operações geradas pelo crescimento das atividades de produção, troca e distribuição de serviços que já não limitam seu campo de ação às fronteiras da simetria e da disponibilidade de informação para se concretizarem.

A incompletude contratual pode se expressar de várias formas cujos conceitos são identificados na doutrina estrangeira, quais sejam, os contratos de incompletude súbita e incompletude deliberada, incompletude inicial e incompletude sucessiva, incompletude jurídica e incompletude econômica. Cabe ao ordenamento jurídico completar os contratos, guardando sempre o cuidado de não incorrer em onerosidade excessiva e dar-lhes a efetividade e eficácia desejadas.

Em sendo um meio alternativo de gerir riscos supervenientes, o contrato incompleto tem características distintas daquelas reconhecidas pela teoria da imprevisão. Suas "lacunas" servem às partes para introduzir na relação aquela flexibilidade necessária para que o contrato possa continuamente adequar-se às mudanças das circunstâncias, por isso se reconhece que o contrato incompleto é um meio alternativo de gerir situações supervenientes.

O contrato relacional, um tipo de contrato incompleto, tem como vantagem não ser apenas governado pela regra legal, mas também pela regra extralegal proveniente da mesma relação. Tais regras incentivam as partes a proceder corretamente na fase de execução do contrato, ainda mais se ocorrerem mudanças de circunstâncias. As partes se utilizam de "remédios" extrajurídicos para sanear futuras contingências.

Sua divergência do modelo clássico do direito dos contratos é mais evidente quando o contrato não é adimplido nas condições previstas, deve o jurista afastar a 
aplicação da teoria da imprevisão, devendo incentivar as partes, quando da ocorrência de circunstâncias supervenientes, a adotar um clima de cooperação, gerindo ex post a contingência não prevista, em conformidade com a teoria do contrato incompleto.

Há um longo caminho a ser percorrido até se chegar ao contrato incompleto como solução ideal para os contratos de longo termo. É imprescindível a cooperação entre as partes, a eliminação de cláusulas de onerosidade excessiva e o reconhecimento da importância de eliminar custos transacionais desnecessários, deixando em aberto determinadas previsões contratuais a serem dirimidas ex post.

É, sim, possível concluir que a teoria econômica do contrato incompleto amplia a hipótese de revisão que se baseia na teoria da imprevisão, inovando, portanto, a ordem jurídica e abrindo novos caminhos para esse novo tipo de contrato que se impõe ao Brasil que começa a trilhar rumo à estabilidade financeira e assegurar aos contratantes uma base mais sólida e possível para permitir a "ousadia" dos contratos de longa duração.

: ARTIGO APROVADO (18/03/2014) : RECEBIDO EM 14/01/2013

\section{NOTAS}

1 "As ciências econômicas estudam a atividade produtiva não somente sob o aspecto do preço, mas considerando a alocação de recursos conforme as leis e os mecanismos de sua aplicação presentes na realidade dos agentes econômicos." (CATEB; GALLO, 2010, p. 1)

2 "Contratos completos seriam aqueles capazes de especificar, em tese, todas as características físicas de uma transação, como data, localização, preço e quantidades, para cada estado da natureza futuro. Em um contrato completo, a princípio, não haveria necessidade de verificação ou determinação adicional dos direitos e obrigações das partes durante sua execução, já que o instrumento delinearia todas as possibilidades de eventos futuros envolvidos com o objeto da contratação." (CATEB; GALLO, 2010, p. 2)

3 Os textos em Italiano foram traduzidos livremente pelas autoras.

4 Aqui, cooperação pode ser definida como "associação com outrem para benefício mútuo ou para a divisão mútua de ônus." (CATEB; GALLO, 2010, p. 5)

5 “Transações que implicam a passagem do tempo para que sejam concluídas. Por exemplo: uma parte paga agora e a outra promete entregar mercadorias mais tarde; uma parte entrega mercadorias agora e a outra promete pagar mais tarde; ou uma parte promete entregar mercadorias mais tarde, e a outra promete pagar quando as mercadorias forem entregues." (COOTER; ULEN, 2010, p. 208)

6 "Tali lacune ricorrono di regola naturalmente in un contratto; si tratta di una circostanza da sempre nota e affermata; l'incompletezza del contrato è conseguenza, di fatto, delle tecniche di contrattazione elo delle diverse modalità di conclusione del 
contratto, differenziate le une come le altre anche e soprattutto in relazione al livello di "complessità" del contratto stesso." (GUERINONI, 2007, p. 2)

7 Na referida obra, Bobbio (1999, p. 115-118) adverte: "Por 'completude' entende-se a propriedade pela qual um ordenamento jurídico tem uma norma para regular qualquer caso. Uma vez que a falta de uma norma se chama geralmente 'lacuna' (num dos sentidos do termo 'lacuna'), 'completude' significa 'falta de lacunas'. Em outras palavras, um ordenamento é completo quando o juiz pode encontrar nele uma norma para regular qualquer caso que se lhe apresente, ou melhor, não há caso que não possa ser regulado com uma norma tirada do sistema. [...] A base dos ordenamentos fundados sobre o dogma da completude, como já foi dito, é o Código Civil francês, cujo artigo $4^{\circ}$ diz: 'O juiz que recusar julgar, a pretexto do silêncio, da obscuridade ou da insuficiência da lei, poderá ser processado como culpado de denegar a justiça'. [...] Concluindo, a completude é uma condição necessária para os ordenamnetos em que valem estas duas regras: 1) o juiz é obrigado a julgar todas as controvérsias que se apresentarem a seu exame; 2) deve julgá-las com base em uma norma pertencente ao sistema”.

8 "Le lacune, peraltro, possono essere o subite dalle parti, ovvero da loro deliberate. Le prime si hanno quando $i$ contraenti non regolamentano, all'atto della conclusione del contrato, un determinato aspetto del loro rapporto né prevedono alcun meccanismo di successiva determinazione di quell'aspetto, lasciando cosi (più o meno scientemente) incompleto e (più o meno scientemente) preferendo che questo venga disciplinato dalle norme di legge (mediante il procedimento dell'integrazione)." (GUERINONI, 2007, p. 3)

9 Os aspectos da racionalidade são: 1) coerência das escolhas; 2) capacidade de compreender as consequências das próprias decisões; 3) capacidade ilimitada de computação também na presença de opções complexas; 4) pleno conhecimento das circunstâncias, atuais e futuras e também incertas e prováveis; 5) coerência também em sentido diacrônico; 6) comum percepção da realidade (as partes têm os mesmos conhecimentos) (FICI, 2000, p. 93).

10 Salama (2010, p. 23-24) ilustra: "suponha que uma empresa saiba que seus produtos às vezes causarão danos aos seus consumidores. Por exemplo, uma empresa de transporte aéreo sabe que existe a possibilidade de que haja acidentes aéreos. Quanto a empresa investirá para tornar seus vôos mais seguros? Como as empresas têm por objetivo maximizarem seus lucros e remunerarem seus acionistas, a resposta dependerá principalmente das seguintes variáveis: a) dos custos para tornar os produtos e serviços mais seguros (por exemplo, os custos para treinamento de pessoal, manutenção de aviões, desenvolvimento de novas tecnologias, etc), b) da probabilidade de ocorrência de acidentes com cada uma das possíveis tecnologias e métodos de segurança que podem ser empregadas; c) dos danos à reputação da empresa no caso de acidentes (por exemplo, por causa da diminuição da procura por passagens aéreas após um acidente); d) dos custos relacionados à responsabilização civil por danos causados (especialmente pagamentos de indenizações a vítimas e de multas ao governo); etc. [...]. De posse dessas estimativas, a empresa investirá para tornar seus produtos e serviços mais seguros até o ponto em que tais investimentos se paguem. Vale dizer: a empresa investirá em segurança até o ponto em que os custos marginais forem iguais aos benefícios marginais. No momento em que os investimentos em segurança causarem mais custos do que benefícios, a empresa deixará de investir em segurança”.

11 “A teoria dos jogos é muito utilizada nos ramos da matemática e economia, porém, demais áreas como computação, sociologia, biologia, ciências políticas e direito já estudam a sua aplicabilidade dentro do seu campo de atuação. Pela definição de Carvalho (2007, p. 215), "a teoria dos jogos é um método utilizado para representar e compreender as decisões tomadas por agentes que interagem entre si. Também é correto afirmar que, a partir dessa compreensão, constitui um meio para a adoção da melhor escolha nos casos de interação estratégica”. Dentre os seus principais precursores, encontram-se o francês Emile Borel, que em 1921 já havia publicado la théorie du jeu, Von Neumann e Oskar Morgenstern, que em 1944 publicaram o livro The Theory of Games and Economic Behavior e John Nash, 1951, com os artigos Non-cooperative games, The bargaining problem e Two-person cooperative games. Sobre o panorama histórico da teoria dos jogos, Russel (2004, p. 623) escreve, "as raízes mais antigas da teoria dos jogos podem ser localizadas em propostas feitas no século XVII por Christiaan Huygens e Gottfried Leibniz para estudar interações humanas competitivas e cooperativas de forma científica e matemática. Ao longo do século XIX, vários economistas importantes criaram exemplos matemáticos simples para analisar casos específicos de situações competitivas. Os primeiros resultados formais em teoria dos jogos se devem a Zermelo (1913). Emile Borel (1921) introduziu a noção de uma estratégia mista. A colaboração de Von Neumann com o economista Oskar Morgenstern levou à publicação em 1944 do volume Theory of Games and Economic Behavior, o livro definitivo sobre teoria dos jogos [...]. Em 1950, com 21 anos de idade, John Nash publicou suas ideias relativas a equilíbrios em jogos gerais. Sua definição de uma solução de equilíbrio, embora se originasse do trabalho de Cournot (1838), ficou conhecida como equilíbrio de Nash'. Através do estudo da teoria dos jogos, é possível detectar qual é a melhor opção a ser tomada por um jogador quando diante de uma dada 
situação, devendo os agentes econômicos seguir determinada estratégia tendo sempre como base a estratégia do outro. A escola de direito e economia utiliza a teoria dos jogos para analisar como as 'empresas interagem, dadas as normas legais, e para entender como elas influenciam seu comportamento estratégico como agentes econômicos ou como partes em litígios de diversos tipos' (PINHEIRO, 2005, p. 157)." (CAMINHA; LIMA, 2009, p. 213)

12 “Também conhecida ao longo dos séculos como cláusula implícita ou tacitamente contida (Bártolo de Sassoferrato), lesão superveniente (Mantica), pressuposição ou vontade condicionada (Windscheid), soppravvenienza ou vontade marginal (Osti), base do negócio jurídico (Oertmann), reserva virtual (Kruckmann), teoria do erro (Giovenne), excessiva onerosidade (Código Civil italiano), alteração das circunstâncias (Código Civil português), teoría de la imprevisión (Código Civil argentino e todos os de língua castelhana, com exceção do Chile) ou, como vige entre nós, Teoria da Imprevisão.” (BORGES, 2006, p. 88)

13 Destacam-se, entre outros, Caio Mário, Washington de Barros, Orlando Gomes, Maria Helena Diniz e Silvio Venosa.

14 "Por isso, a relativização da vinculação contratual foi a solução adotada a fim de se permitir a restituição das partes ao estado jurídico anterior ao fator que provocou o desequilíbrio do ajuste originariamente pactuado. A relativização do contrato encontra fundamento no princípio da conservação do negócio jurídico, o que se torna possível mediante a sua revisão, cujo desiderato é a promoção do reequilíbrio do ajuste originariamente estabelecido, restituindose as partes à comutatividade originária, quando da conclusão do contrato.” (LISBOA, 2010, p. 119)

15 Enunciado n. 176, aprovado na III Jornada de Direito Civil: “em atenção ao princípio da conservação dos negócios jurídicos, o art. 478 do Código Civil de 2002 deverá conduzir, sempre que possível, à revisão judicial dos contratos e não à resolução contratual".

16 “Art. 1467 Contratto con prestazioni corrispettive. Nei contratti a esecuzione continuata o periodica ovvero a esecuzione differita, se la prestazione di una delle parti è divenuta eccessivamente onerosa per il verificarsi di avvenimenti straordinari e imprevedibili, la parte che deve tale prestazione può domandare la risoluzione del contratto, con gli effetti stabiliti dall'Art. 1458 (att. 168). La risoluzione non può essere domandata se la sopravvenuta onerosità rientra nell'alea normale del contratto. La parte contro la quale è domandata la risoluzione può evitarla offrendo di modificare equamente le condizioni del contratto $(962,1623,1664,1923) . "$

17 “Art. 1468 Contratto con obbligazioni di una sola parte. Nell'ipotesi prevista dall'articolo precedente, se si tratta di un contratto nel quale una sola delle parti ha assunto obbligazioni, questa può chiedere una riduzione della sua prestazione ovvero una modificazione nelle modalità di esecuzione, sufficienti per ricondurla ad equità."

18 “Os contratos descontínuos ('discrete contracts') têm como características básicas o fato de serem impessoais, 'presentificadores' ('presentiate') (i.e., tendem a tornar presente o futuro), envolverem uma barganha entre partes instrumentalmente orientadas e requerem o mútuo consentimento das duas partes. Ele é descontínuo e compõe uma entidade separada, na medida em que ele planeja uma transação separada de todas as transações a ela anteriores, contemporâneas ou subseqüentes. Cada ato contratual é considerado um ato isolado, independente e autônomo, pois que tem em si todos os seus elementos essenciais constitutivos. Assim, por exemplo, o contrato de acordo com o Código Civil Brasileiro de 1917, desde que contenha livre manifestação da vontade, objeto lícito, agente capaz e não ofenda a forma prescrita em lei, é considerado ato negócio jurídico perfeito e gerador de efeitos jurídicos, em particular, do efeito vinculante e da executoriedade". (MACEDO JUNIOR, 2010, p. 4-5).

19 "O contrato descontínuo corresponde à definição que o pensamento contratual clássico deu ao contrato tanto na doutrina quanto na elaboração de estatutos e código.” (MACEDO JUNIOR, 2010, p. 5) 


\section{REFERÊNCIAS BIBLIOGRÁFICAS}

ALPA, Guido. Analisi economica del diritto privato. Milano: Giuffrè, 1998.

ARAÚJO, Fernando. Teoria econômica do contrato. Coimbra: Almedina, 2007.

AZEVEDO, Álvaro Villaça. O novo código civil brasileiro: tramitação; função social do contrato; boa-fé objetiva; teoria da imprevisão; e, em especial, onerosidade excessiva. Revista Jurídica, v. 308, p. 7-18, São Paulo, jun. 2003. BACKHOUSE, Roger. História da economia mundial. Tradução Celso Mauro Paciornik. São Paulo: Estação Liberdade, 2007.

BARBOZA, Heloisa Helena. Reflexões sobre a autonomia negocial. In: TEPEDINO, Gustavo; FACHIN, Luiz Edson (Coord.). O direito e o tempo: embates jurídicos e utopias contemporâneas. Rio de Janeiro: Renovar, 2008. p. 407-423.

BRASIL. Superior Tribunal de Justiça (STJ). REsp 112.9738/SP, Relator Ministro Mauro Campbell Marques. Segunda Turma, julgado em 05/10/2010. Dje 21-10-2010. Inteiro teor disponível em: <https://ww2.stj.jus.br/ revistaeletronica/ita.asp?registro $=200901440080 \& d t \_p u b l i c a c a o=21 / 10 / 2010>$. Acesso em: 5 dez. 2010. BRASIL. Superior Tribunal de Justiça (STJ). REsp 473.140/SP, Relator Ministro Carlos Alberto Menezes Direito. Lavrar acórdão Ministro Aldir Passarinho Junior Segunda Turma, julgado em 12/02/2003. Dje 04-08-2003. Inteiro teor disponível em: <https://ww2.stj.jus.br/revistaeletronica/ita.aspregistro= 200201348879\&dt_publicacao=04/08/2003>. Acesso em: 5 dez. 2010.

BRASIL. Superior Tribunal de Justiça (STJ). REsp 343.617/GO, Relator Ministro Antônio de Pádua Ribeiro. Terceira Turma, julgado em 18/06/2002. Dje 16-09-2002. Inteiro teor disponível em: <https://ww2.stj.jus.br $/$ revistaeletronica/ita.asp?registro=200101037251\&dt_publicacao=16/09/2002 >. Acesso em: 5 dez. 2010. BELLANTUONO, Giuseppe. I contratti incompleti nel diritto e nell'economia. Padova: Cedam, 2000.

. Analisi economica del diritto. Trento: Uni-service, 2005.

BITTAR FILHO, Carlos Alberto. Contratos: perfil jurisprudencial no direito brasileiro vigente. Revista dos Tribunais, v. 801, p. 115-123, São Paulo, jul. 2002.

BOBBIO, Norberto. Teoria do ordenamento jurídico. Tradução Maria Celeste C. J. Santos. 10. ed. Brasília:

Universidade de Brasília, 1999.

BORGES, Nelson. Aspectos positivos e negativos da revisão contratual no novo código civil. Revista dos Tribunais, v. 849, p. 80-110, São Paulo, jul. 2006.

CABALLERO, Gonzalo. Instituciones e historia económica: enfoques y teorías institucionales. Revista de Economía Institucional, v. 6, n. 10, p. 135-157, Bogotá, jan./jun. 2004. Disponível em: <www.economiainstitucional.com/ pdf/No10/gcaballero10.pdf>. Acesso em: 8 fev. 2010.

CAMINHA, Uinie; LIMA, Juliana. Poder Judiciário e crédito: aplicação da teoria dos jogos. Pensar: Revista de Ciências Jurídicas, v. 14, n. 1, p. 204-219, Fortaleza, jan./jun. 2009.

CATEB, Alexandre Bueno; GALLO, José Alberto Albeny. Breves considerações sobre a teoria dos contratos incompletos. Disponível em: <http://escholarship.org/uc/item/1bw6c8s9>. Acesso em: 17 jun. 2010.

COASE, Ronald Harry. The firm, the market, and the law. Chicago: University of Chicago Press, 1990.

O problema do custo social. In: SALAMA, Bruno (Org.). Direito e economia: textos escolhidos. São Paulo: Saraiva, 2010. p. 59-112.

23 fev. 2010. El problema del costo social. Disponível em: <www.coase.org/coaseintranslation.htm>. Acesso em:

COOTER, Robert; ULEN, Thomas. Direito e economia. Tradução Luis Marcos Sander, Francisco Araújo da Costa. 5. ed. Porto Alegre: Bookman, 2010.

. Le migliore leggi giuste: i valori fondamentali nell'analisi economica del diritto. In: ALPA, Guido

(Org.). Analisi economica del diritto privato. Milano: Giuffrè, 1998. p. 464-488.

FACHIN, Luiz Edson. Teoria crítica do direito civil. Rio de Janeiro: Renovar, 2003.

FARRELL, Martín Diego. Filosofia del derecho y economia. Buenos Aires: La Ley, 2006.

FICI, Antônio. Il contrato incompleto. Torino: G. Giappichelli, 2005.

FIGUEIREDO, Alcio Manoel de Sousa. Cláusula rebus sic stantibus: teoria da imprevisão. Revista dos Tribunais, v. 845, p. 725-750, São Paulo, mar. 2006.

GAGLIANO, Pablo Stolze; PAMPLONA FILHO, Rodolfo. Novo curso de direito civil: contratos. 2. ed. São Paulo: Saraiva, 2006.

GALLO, José Alberto Albeny. Contratos incompletos. Disponível em: <www.mcampos.br/POSGRADUACAO/

MESTRADO\%20DIREITO/dissertacoes/josealbertoalbenygallocontratosincompletos.pdf>. Acesso em: 8 fev. 2010. GAMA, Guilherme Calmon Nogueira da. Direito contratual contemporâneo: a função social do contrato. In: TEPEDINO, Gustavo; FACHIN, Luiz Edson (Coord.). O direito e o tempo: embates jurídicos e utopias contemporâneas. Rio de Janeiro: Renovar, 2008. p. 369-393. 
GOMES, Orlando. Contratos. 26. ed. Rio de Janeiro: Forense, 2008. Transformações gerais do direito das obrigações. São Paulo: Revista dos Tribunais, 1967.

GRAU, Eros Roberto. A ordem econômica na Constituição de 1988. 12. ed. São Paulo: Malheiros, 2007.

GONZÁLEZ, José E.; TINTI, Guillermo P.; CALDERÓN, Maximiliano R.; RIBA, Marina A. Teoría general de los contratos. Buenos Aires: Ábaco, 2004.

GRISI, Giuseppe. L'autonomia privata: diritto dei contratti e disciplina costituzionale dell'economia. Milano:

Giuffrè, 1999.

GUERINONI, Ezio. Incompletezza e completamento del contratto. Milano: Giuffrè, 2007.

HUISMAN, Denis. Dicionário dos filósofos. São Paulo: Martins Fontes, 2001.

HUNT, E. K. História do pensamento econômico. Tradução José Ricardo Brandão Azevedo. 7. ed. Rio de Janeiro: Campus, 1989.

ITURRASPE, Jorge Mosset; PIEDECASAS, Miguel A. Responsabilidad civil y contratos: La revisión del contrato. Santa Fé: Rubinzal Culzoni, 2008.

LEITE, Gisele. Evolução doutrinária do contrato. Disponível em: <www.planalto.gov.br/ccivil_03/revista/ REV_86/artigos/GiseleLeite_rev86.htm>. Acesso em: 2 dez. 2010.

LISBOA, Roberto Senise. Manual de direito civil. 5. ed. São Paulo: Saraiva, 2010.

LOURENÇO, José. Limites à liberdade de contratar: princípios da autonomia e da heteronomia da vontade nos negócios jurídicos. São Paulo: J. de Oliveira, 2001.

MACARIO, Francesco. Adeguamento e rinegoziazione nei contratti a lungo termine. [S. 1.]: Jovene, 1996.

MACEDO JUNIOR, Ronaldo Porto. Contratos relacionais do direito brasileiro. Disponível em:

<www.lasa.international.pitt.edu/LASA97/portomacedo.pdf>. Acesso em: 8 fev. 2010.

MARASCO, Gherardo. La rinegoziazione del contratto - Strumenti legali e convenzionale a tutela dell'equilibrio negoziale. [S. 1.]: Cedam, 2006.

MORELLO, Augusto M. La adecuación del contrato: por las partes, por el juez, por los árbitros. La Plata: Libreria Platense, 1994.

NORTH, Douglass C. Institutions, institutional change and economic performance. New York: Cambridge, 2009.

NUSDEO, Fábio. Curso de economia. 4. ed. São Paulo: Revista dos Tribunais, 2005.

PEREIRA, Caio Mário da Silva. Instituições de direito civil. 5. ed. Rio de Janeiro: Forense, 1984.

PERLINGIERI, Pietro. Perfis do direito civil. 3. ed. Rio de Janeiro: Renovar, 2002.

PINHEIRO, Armando Castelar; SADDI, Jairo. Direito, economia e mercados. Rio de Janeiro: Elsevier, 2005.

PINHEIRO, Armando Castelar. Segurança jurídica, crescimento e exportações. Disponível em: <www.ipea.gov.br/ $\mathrm{pub} / \mathrm{td} / 2005 / \mathrm{td} \_1125 . \mathrm{pdf}>$. Acesso em: 17 jun. 2010.

POSNER, Eric. Análise econômica do direito contratual: sucesso ou fracasso? Tradução Luciana Benetti Timm, Cristiano Carvalho e Alexandre Viola. São Paulo: Saraiva, 2010.

POSNER, Richard. L'economia e il giurista. In: ALPA, Guido (Org.). Analisi economica del diritto privato. Milano: Giuffrè, 1998. p. 48-54.

PRATA, Ana. A tutela constitucional da autonomia privada. Coimbra: Almedina, 1982.

REALE, Miguel. A boa-fé no código civil. Disponível em: <www.miguelreale.com.br/artigos/boafe.htm>. Acesso em: 2 dez. 2010. dez. 2010. O novo código civil. Disponível em: <www.sescsp.net/sesc/revistas_sesc/pb/artigo.cfm>. Acesso em: 2

RIBEIRO, Marcia Carla Pereira. Teoria geral dos contratos: contratos empresariais e análise econômica. Rio de Janeiro: Elsevier, 2009.

RODOTÀ, Stefano. Le fonti di integrazione del contratto. [S. 1.]: Giuffrè, 2004

RODRIGUES JUNIOR, Otavio Luiz. Autonomia da vontade, autonomia privada e autodeterminação. Revista de Informação Legislativa, v. 41, n. 163, p. 113-130, Brasília, jul./set. 2004

ROPPO, Enzo. O contrato. Coimbra: Almedina, 1988.

SADDI, Jairo. Crise e regulação bancárias. São Paulo: Texto Novo, 2001 Crédito e Judiciário no Brasil. São Paulo: Quartier Latin, 2007.

SALAMA, Bruno Meyerhof (Org.) Direito e economia: textos escolhidos. São Paulo: Saraiva, 2010.

SANTANA, Edvaldo Alves de. Instituições, governança econômica e incompletude dos contratos: teoria e prática. Disponível em: <www.anpec.org.br/encontro2008/artigos/200807210909450-.pdf>. Acesso em: 23 fev. 2010.

SMITH, Adam. Uma investigação sobre a natureza e causas da riqueza das nações. Tradução Noberto de Paula Lima. Curitiba: Hemus, 2001

SZTJAN, Rachel. Função social do contrato e direito de empresa. Revista de direito mercantil: industrial, econômico e financeiro, v. 44, p. 29-49, São Paulo, jul. 2005. 
Supply chain e incompletude contratual. Disponível em: <www.revistassystemas.com.br/index.php/ systemas/article/viewPDFInterstitial/10/11>. Acesso em: 10 jun. 2010.

SZTAJN, Rachel; ZYLBERSZTAJN, Decio. Direito e economia: análise econômica do direito e das organizações. Rio de Janeiro: Campus, 2005.

TEPEDINO, Gustavo; FACHIN, Luiz Edson (Coord.). O direito e o tempo: embates jurídicos e utopias contemporâneas - Estudos em homenagem ao professor Ricardo Pereira Lira. Rio de Janeiro: Renovar, 2008. ZYLBERSZTAJN, Decio. A organização ética: um ensaio sobre as relações entre ambiente econômico e o comportamento das organizações. Disponível em: <www.ead.fea.usp.br/whapers/2000/erudicao.pdf>. Acesso em: 17 jun. 2010.

WILLIAMSON, O.E. I costi transattivi e la disciplina del contratto. In: ALPA, Guido (Org.). Analisi economica del diritto privato. Milano: Giuffrè, 1998. p. 149-171.

\section{Uinie Caminha}

Unifor - Centro de Ciências Jurídicas Av. Washington Soares, 132 Edson Queiroz - 60811-905 Fortaleza - CE - Brasil ucaminhalaunifor.br

Unifor - Centro de Ciências Jurídicas Av. Washington Soares, 1321

Edson Queiroz - 60811-905 Fortaleza - CE - Brasil juclimalahotmail.com
Doutora em DiReito Pela Universidade de São Paulo Professora Titular dA Universidade dE Fortaleza E Adjunta da Universidade FEdERAL do CEARÁ ADVogadA

\author{
Juliana Cardoso Lima
}

Mestre em Direito pela Universidade de Fortaleza | 
